\title{
ANODIC SELECTIVE FUNCTIONALIZATION OF CYCLIC AMINE DERIVATIVES
}

\section{Osamu Onomura}

Graduate School of Biomedical Sciences, Nagasaki University, 1-14, Bunkyo-machi, Nagasaki 852-8521, Japan. E-mail: onomura@nagasaki-u.ac.jp

\begin{abstract}
Anodic reactions are desirable methods from the viewpoint of Green Chemistry, since no toxic oxidants are necessary for the oxidation of organic molecules. This review introduces usefulness of anodic oxidation and successive reaction for selective functionalization of cyclic amine derivatives.
\end{abstract}

\section{CONTENTS}

1. Introduction

2. Anodic oxidation of cyclic amine derivatives

2-1. Regioselectivity

2-2. Diastereoselectivity

2-3. Enantioselectivity

2-4. Anodic cyclization

3. Synthetic application of anodic product

3-1. Nucleophilic substitution

3-2. Diastereoselective nucleophilic substitution

3-3. Enantioselective nucleophilic substitution

3-4. Electrophilic substitution

3-5. Preparation of azabicyclic compounds

4. Conclusion

\section{INTRODUCTION}

It is well-known that anodic oxidation is useful for selective functionalization of $N$-protected cyclic amine derivatives. $^{1-3}$ Especially, Shono and Matsumura's pioneer works enabled Lewis acid mediated Mannich-type reaction between $\mathrm{N}, \mathrm{O}$-acetals $\mathbf{B}$ prepared by anodic oxidation of amine derivatives $\mathbf{A}$ and carbon nucleophiles $\left(\mathrm{Nu}^{-}\right)$is one of the powerful methods for synthesis of $\alpha$-substituted amine derivatives C (Scheme 1). ${ }^{4}$ In these reactions, $N$-acyliminium ions $\mathbf{D}$ are key intermediates. ${ }^{5}$ Recently, excellent 
methods for oxidation and/or amidoalkylation of carbamates, such as the "cation pool method", 6 the "cation flow method", "recyclable solid supported bases", 8 and "parallel electrosynthesis"9 were developed.

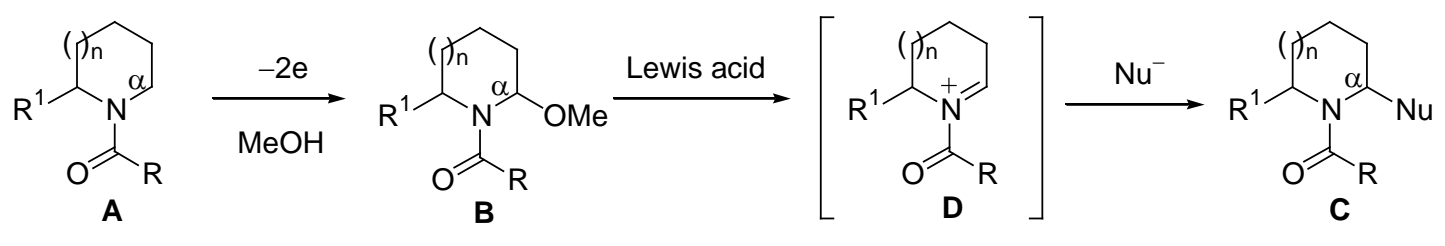

$\mathrm{Nu}$ : Ar, Het-Ar, alkyl, allyl, CN, active methylene, $\mathrm{PO}(\mathrm{OR})_{2}$, etc

Scheme 1 . Anodic $\alpha$-functionalization of cyclic amine derivatives

As shown in Scheme 2, removal of alcohols from $\mathrm{N}, \mathrm{O}$-acetals $\mathbf{B}$ generated enamine derivatives $\mathbf{E}$ which reacted with electrophiles to afford $\beta$-substituted enamines $\mathbf{F} .{ }^{10}$ Anodic oxidation of $\mathbf{E}$ in acetic acid gave $\alpha, \beta$-diacetoxylated amines $\mathbf{G}$ which were directly obtained from amines $\mathbf{A}$ by anodic oxidation in acetic acid. Lewis acid promoted nucleohilic substitution gave $\beta$-acetoxy- $\alpha$-substituted amines $\mathbf{H}^{11}$
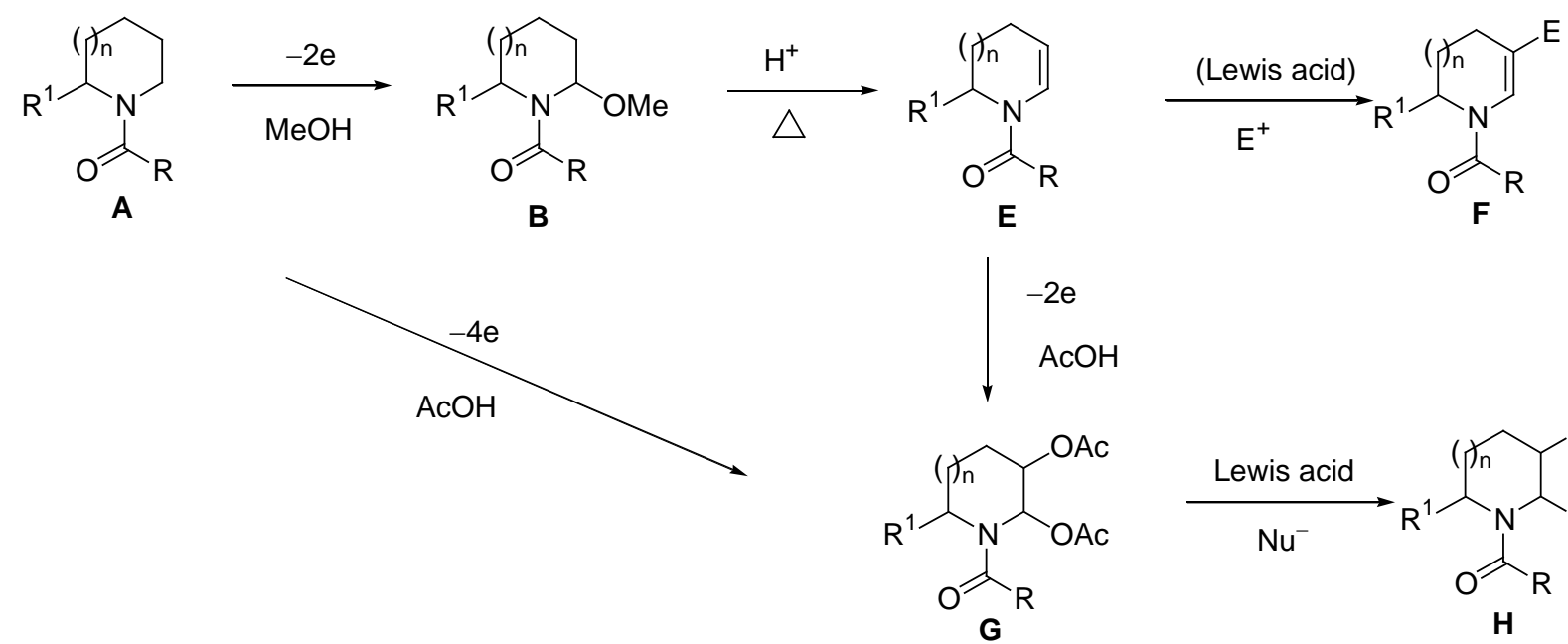

Scheme 2. Anodic $\beta$-functionalization of cyclic amine derivatives

Anodic oxidation of $\mathbf{A}$ or $\mathbf{E}$ in the presence of halogen ion $\left(\mathrm{X}^{-}\right)$afforded $\beta$-halogeno- $\alpha$-methoxylated amines $\mathbf{I}^{12}$ Dehydrohalogenation of $\mathbf{I}$ effectively afforded $\alpha$-methoxy- $\beta, \gamma$-unsaturated amines $\mathbf{J}$ which were not only synthetic precursors for 1,2-dihydropyridines $\mathbf{K}^{13}$ but also $\gamma$-substituted enamines $\mathbf{L}$. ${ }^{14}$ Also, Lewis acid promoted nucleophlic substitution of $\mathbf{I}$ afforded $\beta$-halogeno- $\alpha$-substituted amines $\mathbf{M}$. When $\mathrm{Nu}$ was the active methylene groups, base catalyzed migration of the methylene groups occurred to give $\beta$-substituted enamines $\mathbf{N}$ (Nu=active methylene). ${ }^{15}$ Similarly, aryl groups of $\beta$-halogeno- $\alpha$-arylated 
amines $\mathbf{M}(\mathrm{Nu}=\mathrm{Ar})$ were easily shifted to the $\beta$-position by $\mathrm{Ag}^{+}$(Scheme 3). ${ }^{16}$

This review majorly introduces recent progress on anodic method for selective functionalization of cyclic amine derivatives developed by our group.

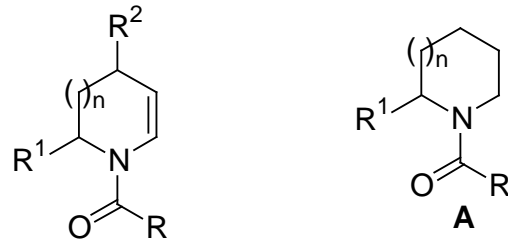

L<smiles>[Y20][R16]</smiles>

$\mathrm{CuBr}$
A

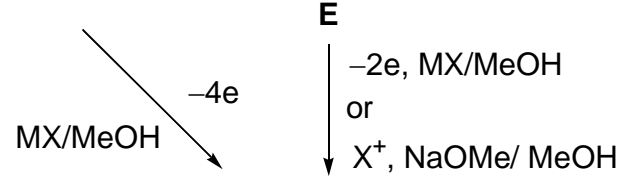<smiles>[R]C(=O)N1C=C([NH])CCC1[R]</smiles>

$\underset{\text { or }}{\text { base }} \uparrow \mathrm{Ag}^{+}$<smiles>[R]C(=O)N1C=CC=CC1[R]</smiles>

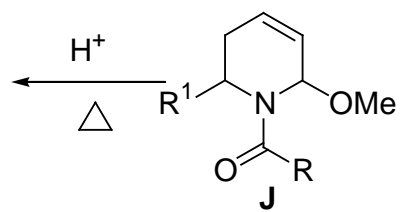<smiles>[R]C(=O)N1C([R])CCCC1[Y]</smiles>

$\mathrm{X}=\mathrm{Cl}, \mathrm{Br}, \mathrm{I} \quad \mathrm{Nu} \quad$ active methylene, $\mathrm{Ar}$

Scheme 3. Further functionalization of $\beta$-halogeno- $\alpha$-methoxylated amines I

\section{ANODIC OXIDATION OF CYCLIC AMINE DERIVATIVES}

\section{2-1. Regioselectivity}

Usually, direct electrochemical oxidation of $N$-acylated cyclic amine derivatives A as shown in Scheme 1 occurred at the less substituted carbon because of steric factor between substrate and anode, while some methods for electrochemical oxidation at the more substituted carbon were developed. Namely, electrochemical oxidation of bicyclic amine prepared from $(S)$-prolinol and trifluoroacetaldehyde proceeded to afford enantiomerically pure methoxylated compound in excellent regioselectivity. This product was easily transformed into $(S)$ - $\alpha$-allylprolinol (Scheme 4$).{ }^{17}$ Also, $N$-cyano cyclic amines were regioselectively methoxylated at the more substituted carbon by electrochemical oxidation (Scheme 5). ${ }^{18}$ Such unusual selectivity might be explained by stability of the corresponding intermediary iminium ions.

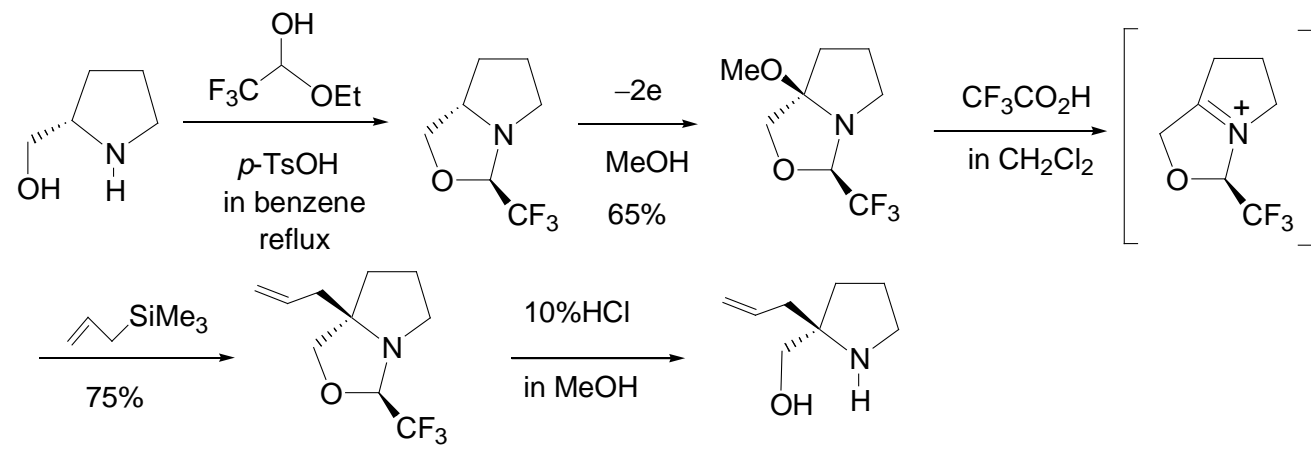

Scheme 4. Anodic synthesis of (S)- $\alpha$-allylprolinol 


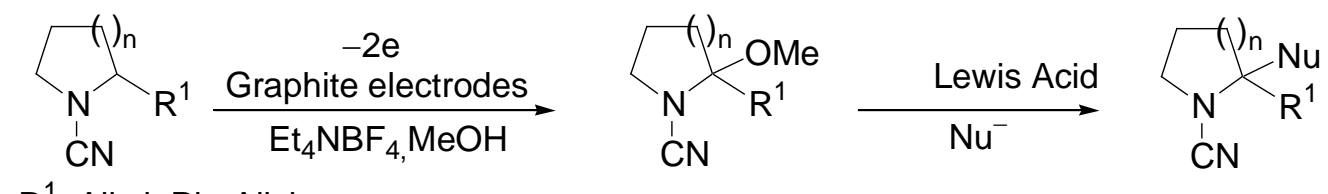
$\mathrm{R}^{1}=\mathrm{Alkyl}, \mathrm{Ph}, \mathrm{Allyl} \quad$ up to $100 \%$ regioselectivity

Scheme 5. Anodic oxidation of $N$-cyano cyclic amines

On the other hand, Dhimane reported that anodic oxidation of bicyclic carbamate afforded a mixture of regio isomers (Eq. 1). ${ }^{19}$

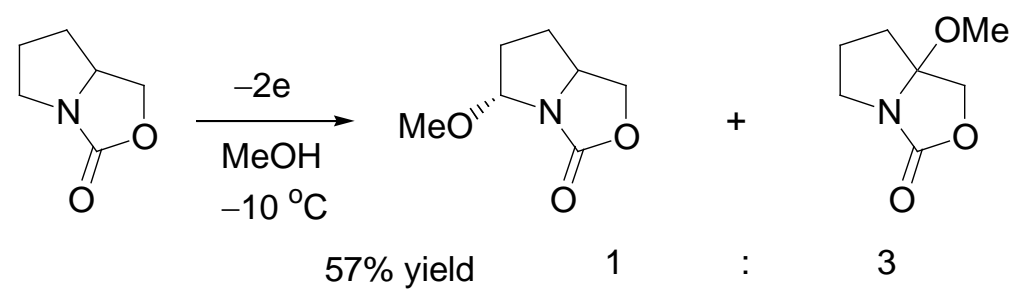

\section{2-2. Diastereoselectivity}

A highly efficient direct cyanation of $N$-protected cyclic amines by anodic oxidation was developed. ${ }^{20}$ The regioselectivity was similar to the anodic methoxylation of $N$-protected cyclic amines. This anodic cyanation of L-proline derivative proceeded to afford 5-cis substituted product in excellent diastereoselectivity (Scheme 6).
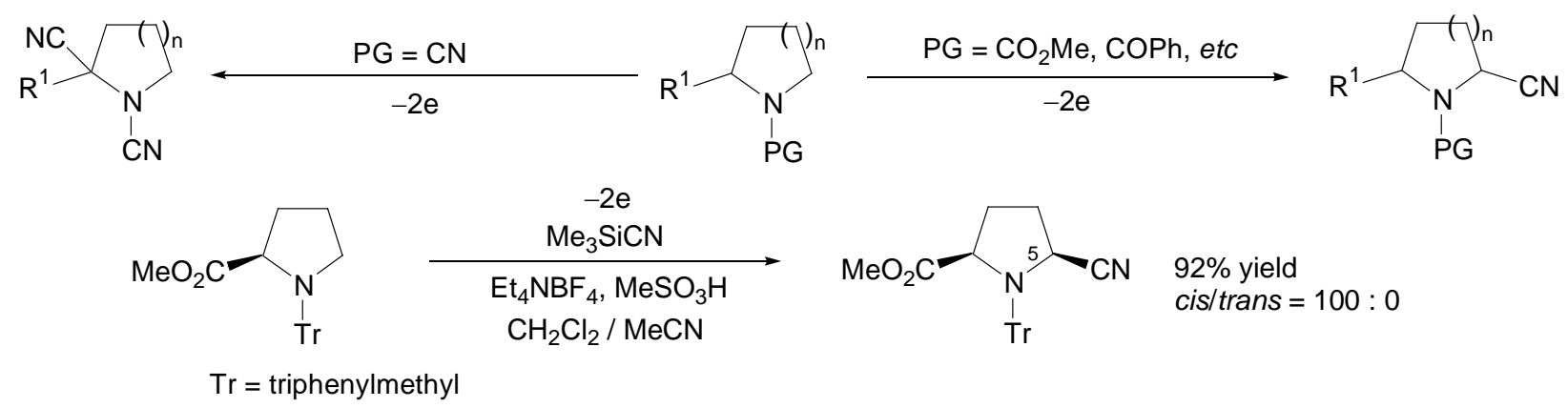

Scheme 6. Regio- and/or diastereo-selective cyanation

Also, under acidic conditions, electrochemical $\alpha$-cyanation of cyclic amines proceeded selectively (Eq. 2). ${ }^{21}$

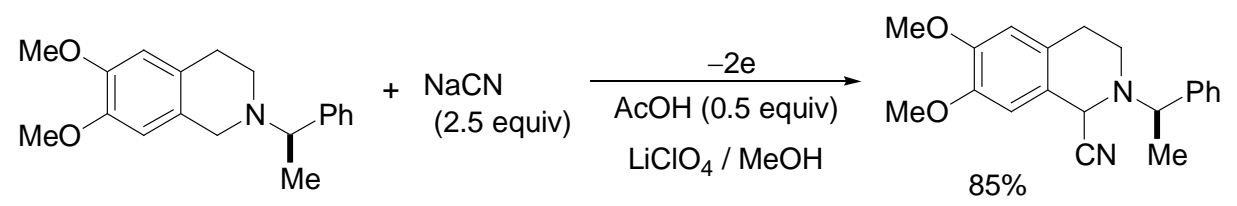

Recently, Pilli and Santos published their work ${ }^{22}$ on electrochemical cyanation using two methods. In the case of the "cation pool" method ${ }^{23}$ using a combination of TMSCN and TMSOTf, they achieved 
high yield and enantioselectivity, on the other hand use of the "non-cation pool” electrochemical method using TMSCN gave very low yield and required low temperatures $\left(-78{ }^{\circ} \mathrm{C}\right)$. In addition Tajima has published their work on electrochemical cyanation based on the concept of site isolation. ${ }^{24}$

Since $N$-protected enamines are representative electron-rich olefins, they are relatively oxidizable. Direct electrochemical oxidation of 6-acetoxymethyl-2,3-didehydropiperidine derivative afforded 3,6-trans isomer, while indirect one gave 3,6-cis isomer in high diastereoselectivity. On the other hand, indirect method using $\mathrm{I}^{-}$as a mediator proceeded via inversion of the stereochemistry (Scheme 7). ${ }^{25}$

Direct electrochemical oxidation<smiles>CC(=O)OCC1CCC=CN1C(=O)OCc1ccccc1</smiles><smiles>CC(=O)OCC1CCC(OC(C)=O)C(OC(C)=O)N1C(=O)OCc1ccccc1</smiles>

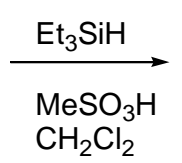<smiles>CC(=O)OC[C@H]1CC[C@@H](OC(C)=O)CN1C(=O)O</smiles>
Indirect electrochemical oxidation<smiles>CC(=O)OCC1CCC=CN1C(=O)OCc1ccccc1</smiles>

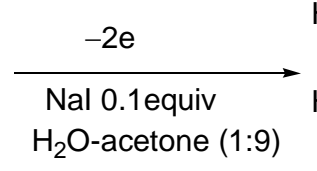<smiles>CC(=O)OCC1CCC(O)C(O)N1C(=O)OCc1ccccc1</smiles><smiles>CCCCCCC</smiles>
cis / trans $=32 / 68$

$\mathrm{HO}$,<smiles>CC(=O)OC[C@H]1CC[C@@H](C)CN1C(=O)OCc1ccccc1</smiles>

$72 \%$ yield cis $/$ trans $=>99 /<1$

Scheme 7. Direct and indirect electrochemical oxidation of enamine derivatives

Although iodohydroxylation afforded 3-trans-iodinated intermediate, successive epoxidation by electrogenerated base (EGB) occurred with the inversion of the stereochemistry at the 3-position (Scheme 8).

On the other hand, $\alpha, \beta$-dihydroxylated cyclic amine derivatives were somewhat unstable to be easily transformed into ring opened hydroxyketones which were changed to imines by acid in the presence of $\mathrm{MgSO}_{4}$. These imines were precursors for $\alpha, \alpha$-disubstituted cyclic amines (Scheme 9). ${ }^{26}$

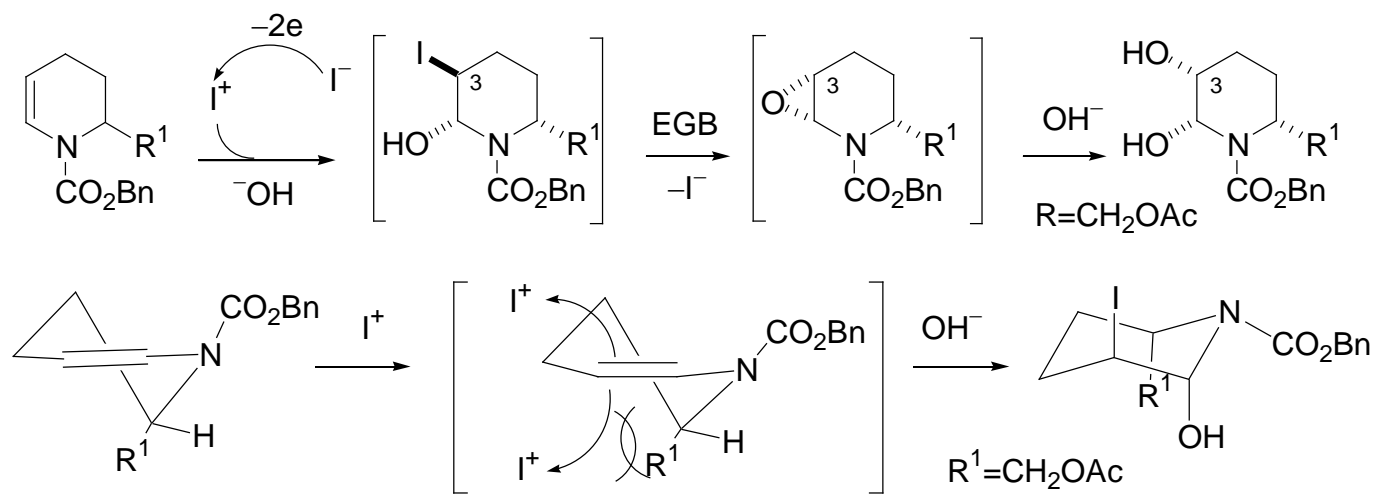

Scheme 8. Stereochemical course for indirect electrochemical oxidation of enamine 


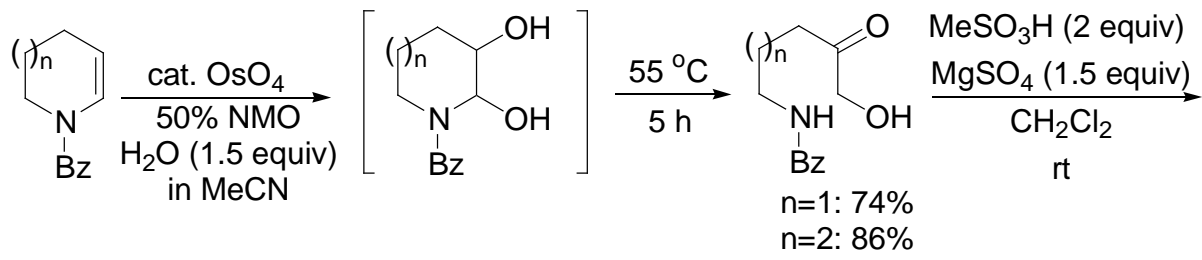

$$
\begin{aligned}
& \text { 策O-MeOH(10:1) } \\
& \mathrm{n}=1: 89 \% \quad \mathrm{n}=1: 90 \% \\
& \mathrm{n}=2: 83 \% \quad \mathrm{n}=2: 98 \%
\end{aligned}
$$

Scheme 9. Ring contraction of $\alpha, \beta$-unsaturated cyclic amine derivatives

The direct oxidation in acetic acid was applicable to $\alpha$-methoxy- $\beta, \gamma$-didehydropiperidine derivatives to afford optically active imino-sugar precursors. In these reactions, $\gamma$-acetoxy- $\alpha, \beta$-didehydropiperidine derivatives generated by acetic acid were anodically oxidized (Scheme 10). ${ }^{27}$

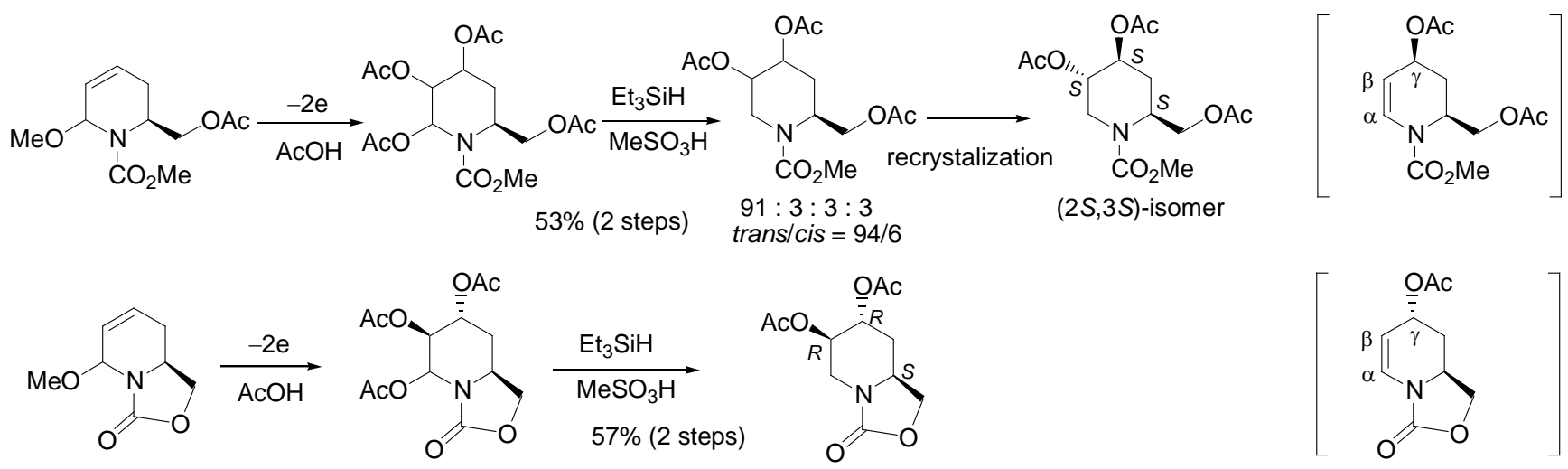

Scheme 10. Diastereoselective preparation of imino-sugar precursors

\section{2-3. Enantioselectivity}

A decaroboxilative methoxylation of an $N$-acylated amino acid (non-Kolbe reaction) leads to $N$-acyl-iminium ion intermediate. ${ }^{28}$ Although transformation of optically active $\alpha$-amino acid into active intermediates without any loss of optical purity is useful for synthesis of optically active nitrogen-containing compounds, intermediary iminium ion which is a typical $\mathrm{sp}^{2}$ cation, might lose the original chirality to afford racemic product (Scheme 11).

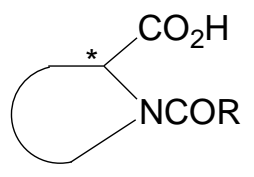

chiral
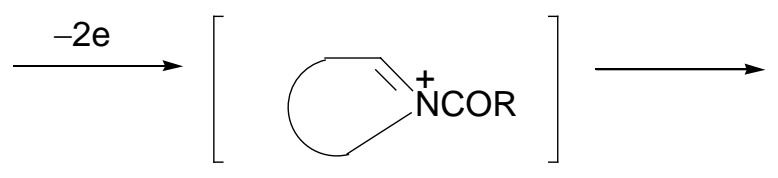

$s p^{2}$ carbon intermediate

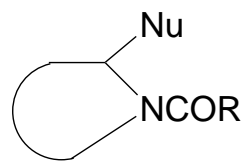

racemic

Scheme 11. Usual anodic decarboxylative substitution of $N$-acyl $\alpha$-amino acids 
However, when $\mathrm{N}$-o-phenylbenzoylated oxazoline and thiazoline derivatives were electrochemically oxidized, the memory of chirality via carbenium ion chemistry occurred to afford optically active products ( $80 \%$ and $91 \%$ enantiomeric excess (ee), respectively) in Eq. 3. ${ }^{29,30}$
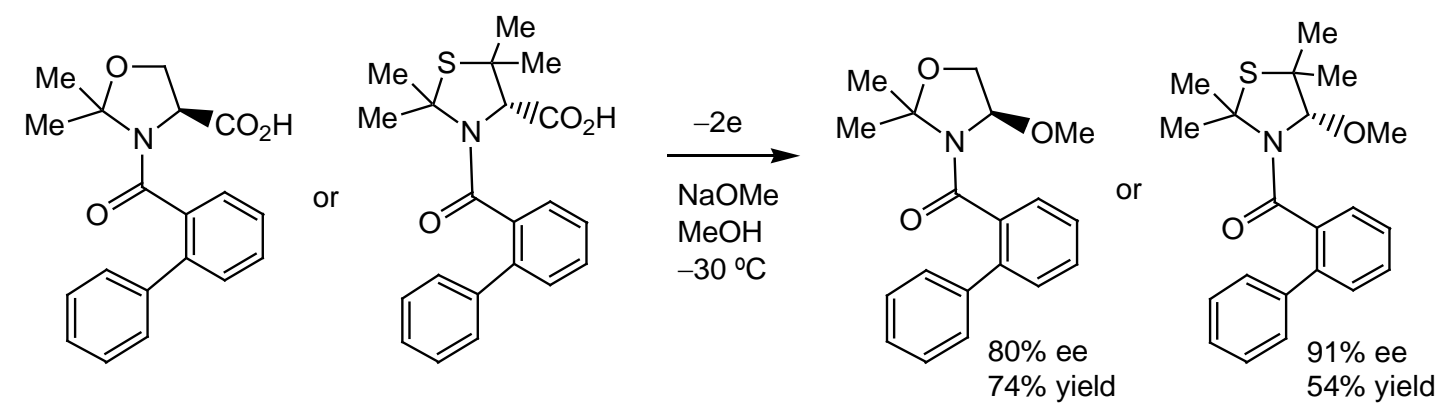

Scheme 12 shows plausible stereochemical course for the memory of chirality. ${ }^{31}$ The initial step involves the oxidative decarboxylation of amino acid to form the iminium ion, which can be attacked by nucleophiles $\left(\mathrm{MeO}^{-}\right)$from the syn or the anti side. The observed $85 \%$ ee could be attributed to the presence of the bulky o-phenyl group beneath the carboxylic group and the fixation of the conformation of amino acid and of iminium ion intermediate at low temperature. The restricted rotation could have favored the formation of a chiral iminium ion with the conformation of an o-phenyl group similar to that of the amino acid. The bulky o-phenyl group could have precluded an effective approach from the anti side, and hence the nucleophilic attack was predominantly from the less hindered syn side resulting in $4 R$-isomer.

Anodic oxidation of $N$-acyl- $\beta$-amino alcohols smoothly cleaves the carbon-carbon bond to afford $\mathrm{N}, \mathrm{O}$-acetals. ${ }^{32}$ The memory of chirality was observed in the anodic substitution of optically active $\beta$-amino alcohol derivatives (Eq. 4). ${ }^{33}$

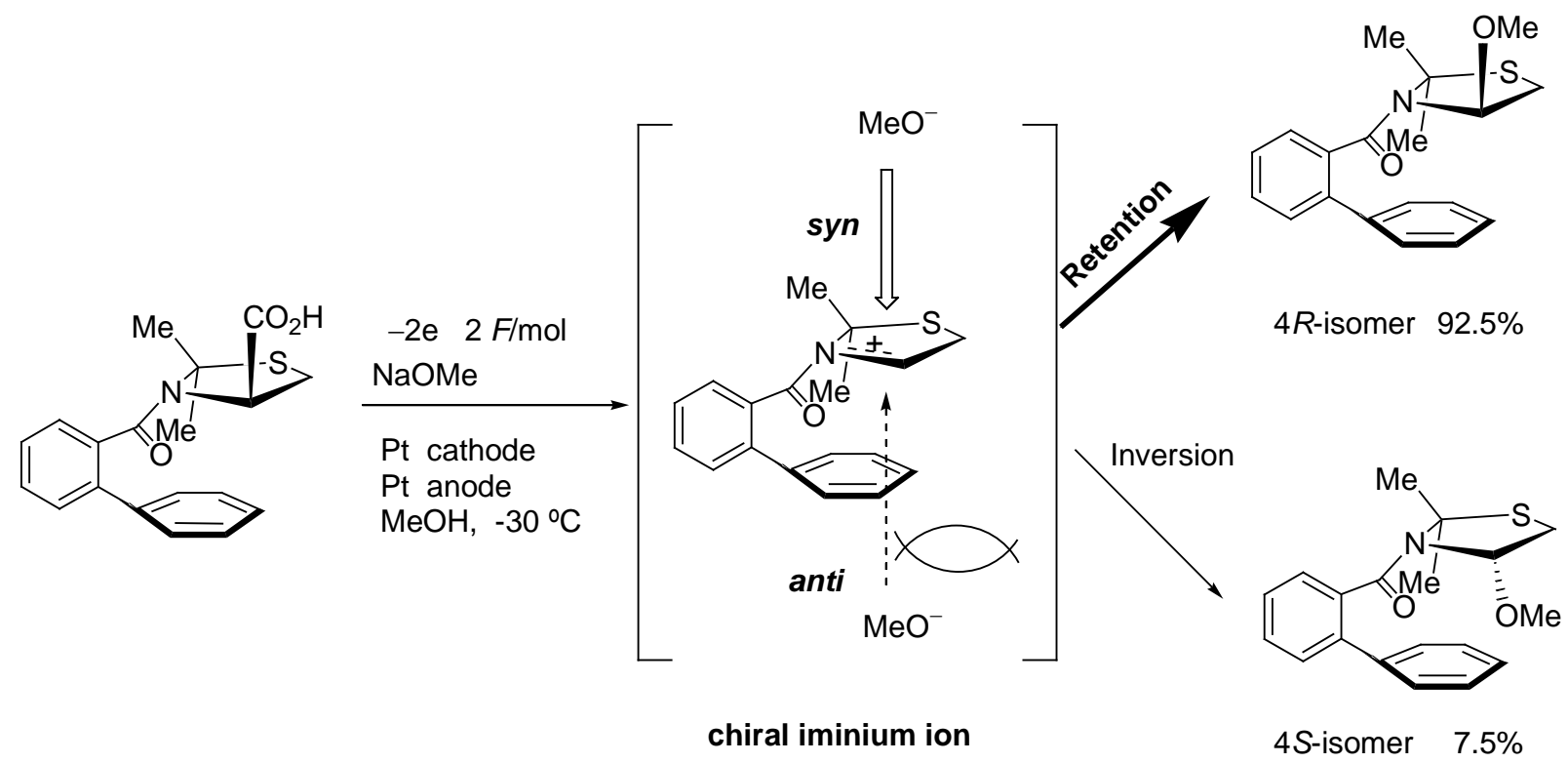

Scheme 12. Plausible stereochemical course for the memory of chirality 

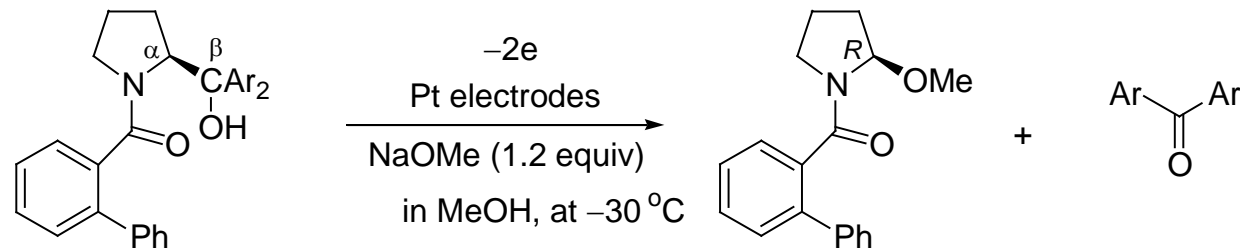

$\mathrm{Ar}=2-\mathrm{MeOPh}: 32 \%$ yield, $73 \%$ ee

$\mathrm{Ar}=4-\mathrm{CF}_{3} \mathrm{Ph}: 44 \%$ yield, $42 \%$ ee

On the other hand, indirect electrochemical oxidation in the presence of chiral copper catalyst transformed racemic $N$-protected aminoalcohols into optically active amino esters in kinetic resolution manner (Scheme 13). ${ }^{34}$ Similar kinetic resolution of racemic $N$-protected aminoalcohols proceeded to afford optically active amino esters. In this reaction, chelation of amino alcohol or amino aldehyde with Lewis acid activate their hydroxyl or formyl group to form alkoxide ion which is easily oxidizable compared with the original amino alcohol or aldehyde (Scheme 14). ${ }^{35}$<smiles>O=C(c1ccccc1)N1CCC[C@H]1CO</smiles>

racemic<smiles>O=C[C@H]1CCCN1C(=O)c1ccccc1</smiles>

racemic $-[\mathrm{e}]$

Pt electrodes, rt $\underset{\mathrm{Et}}{\mathrm{MeOH}} \mathrm{NBr}(1.0$ equiv)

$\mathrm{Cu}(\mathrm{OTf})_{2}$ (0.1 equiv)

$(R, R)$-Ph-BOX (0.1 equiv)

-[e]

Pt electrodes, $\mathrm{rt}$

$\mathrm{Et}_{4} \mathrm{NBr}$ (1.0 equiv)

$\mathrm{Cu}(\mathrm{OTf})_{2}$ (0.1 equiv)

$(R, R)$-Ph-BOX (0.1 equiv)<smiles>COC(=O)[C@@H]1CCCN1C(=O)c1ccccc1</smiles>

(R)-ester

$27 \%$ yield $70 \%$ ee<smiles>COC(=O)[C@H]1CCCN1C(=O)c1ccccc1</smiles>

(R)-ester

$43 \%$ yield $86 \%$ ee<smiles>O=C(c1ccccc1)N1CCCC1CO</smiles>

(S)-alcohol $50 \%$ yield $15 \%$ ee<smiles>O=CC1CCCN1C(=O)c1ccccc1</smiles>
$\mathrm{Ph}$<smiles>CC(C)(C1=NC(P)CO1)C1=NC(c2ccccc2)CO1</smiles>

$\mathrm{L}^{*}(R, R)-\mathrm{Ph}-\mathrm{BOX}$

Scheme 13. Enantioselective oxidation of amino alcohol derivatives

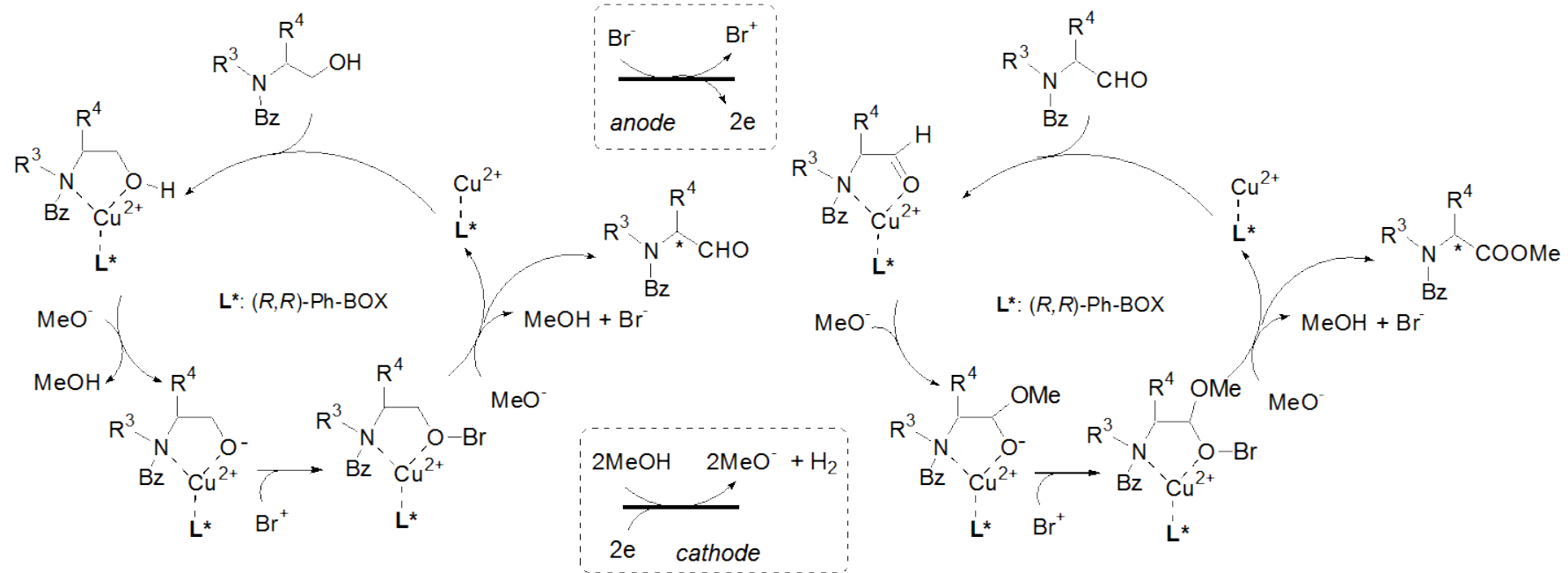

Scheme 14. Reaction mechanism for enantioselective oxidation of amino alcohol or aldehyde 


\section{2-4. Anodic cyclization for preparation of cyclic amine derivatives}

Shono and Matsumura reported that indirect electrochemical intramolecular carbon-nitrogen bond forming reaction of $\mathrm{N}$-tosylaminoalkylmalonates smoothly proceeded to afford cyclic amine derivatives (Scheme 15). ${ }^{36}$

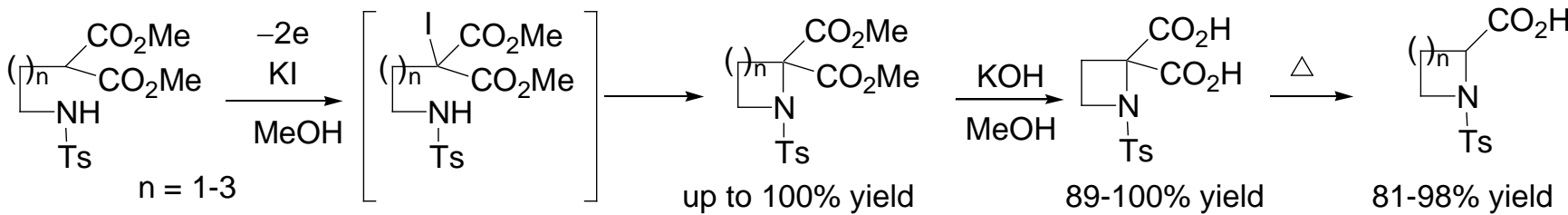

$$
\begin{aligned}
& \underset{\text { pyridine }}{-2 \mathrm{e}} \longrightarrow \\
& 21-34 \% \text { yield }
\end{aligned}
$$

Scheme 15. Coupling of nitrogen and active methylene

Also, Moeller reported that electro-generated radical cations from electron-rich alkenes were intramolecularly trapped with nitrogen to afford cyclic amine derivatives (Scheme 16). ${ }^{37}$

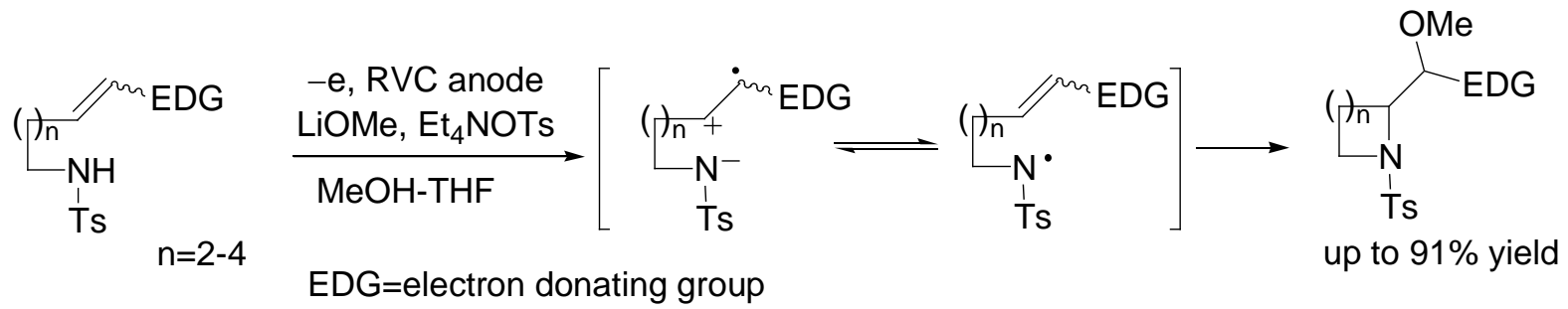

Scheme 16. Coupling of nitrogen and alkene

On the other hand, important intermediate for preparation of carbapenam antibiotics was synthesized by electrochemical intramolecular carbon-carbon bond forming reaction (Scheme 17). ${ }^{38}$ In this cyclization, $(R)$-phenylethyl group works as a good chiral auxiliary.

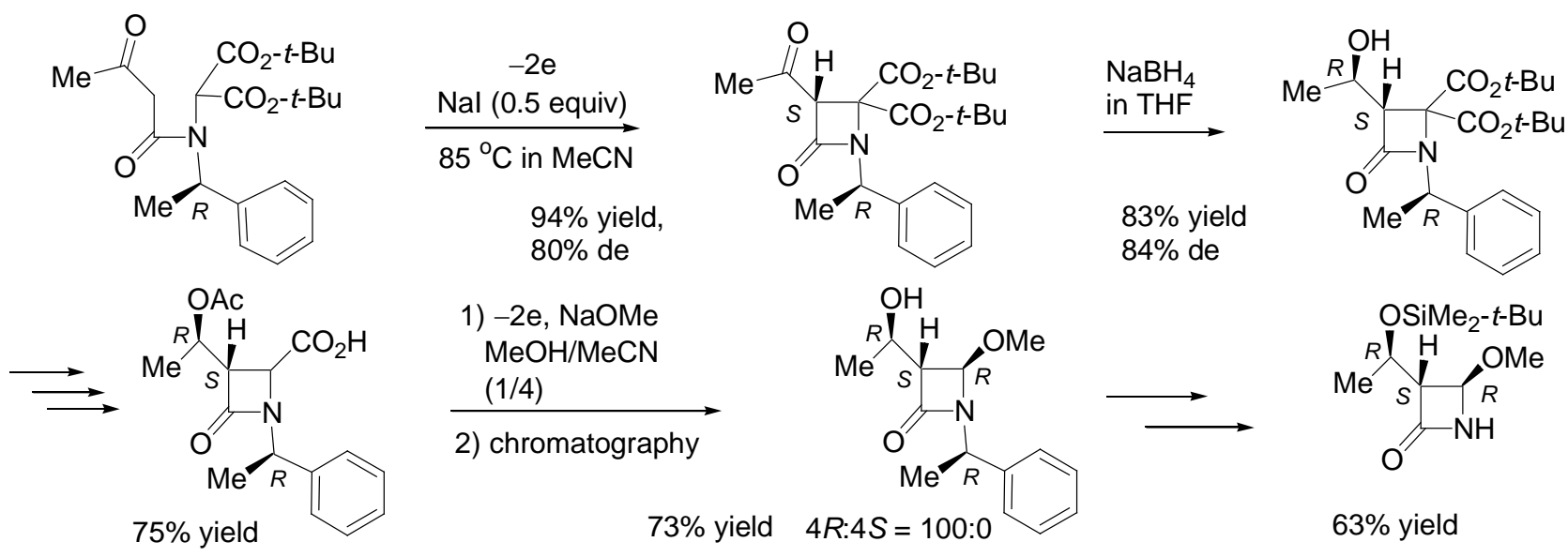

Scheme 17. Electrochemical carbon-carbon forming reaction 


\section{SYNTHETIC APPLICATION OF ANODIC PRODUCT}

\section{3-1. Nucleophilic substitution}

Lewis acid mediated nucleophilic substitution of $\mathrm{N}, \mathrm{O}$-acetals was accomplished under solvent-free condition to afford the substituted products in high yields similar to the yields in dichloromethylene (Eq. 5). ${ }^{39}$ Also, indium-mediated benzylation and allylation of $\alpha$-methoxy- $\beta, \gamma$-unsaturated amines were accelerated in water compared with in tetrahydrofuran (Eq. 6). ${ }^{40}$ Nucleophilic substitution of $N, O$-acetals with unmodified ketones was promoted by a combination of $\mathrm{TiCl}_{4}$ and $\mathrm{PhSiCl}_{3}$ (Eq. 7). ${ }^{41}$ These reactions might be desirable from the viewpoint of Green Chemistry.

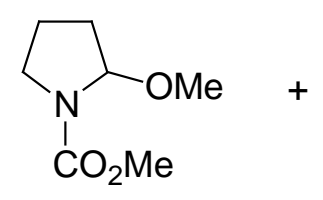

(3.0 equiv)

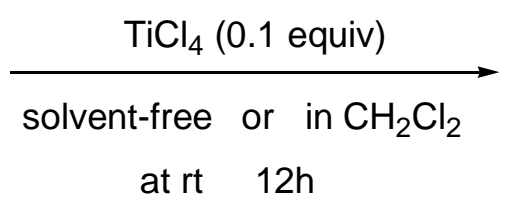

at rt $12 \mathrm{~h}$<smiles>[X]C([X])C1CCCN1C(C)=O</smiles>

$\begin{array}{lll}\mathrm{X}=\mathrm{Y}=\mathrm{COMe} & 89 \% & 70 \% \\ \mathrm{X}=\mathrm{COMe}, \mathrm{Y}=\mathrm{CO}_{2} \mathrm{Me} & 93 \% & 87 \% \\ \mathrm{X}=\mathrm{Y}=\mathrm{CO}_{2} \mathrm{Me} & 76 \% & 80 \%\end{array}$<smiles>COC1C=CCCN1C(C)=O</smiles>

$+$ $\mathrm{R}^{5} \mathrm{Br}$ (2 equiv)<smiles>CC(=O)N1CCC=CC1CP</smiles>

$$
\begin{array}{lcc} 
& \text { in } \mathrm{H}_{2} \mathrm{O} & \text { in THF } \\
\mathrm{R}^{5}=\mathrm{Ph} & 63 \% & 15 \% \\
\mathrm{R}^{5}=\text { vinyl } & 80 \% & 28 \%
\end{array}
$$

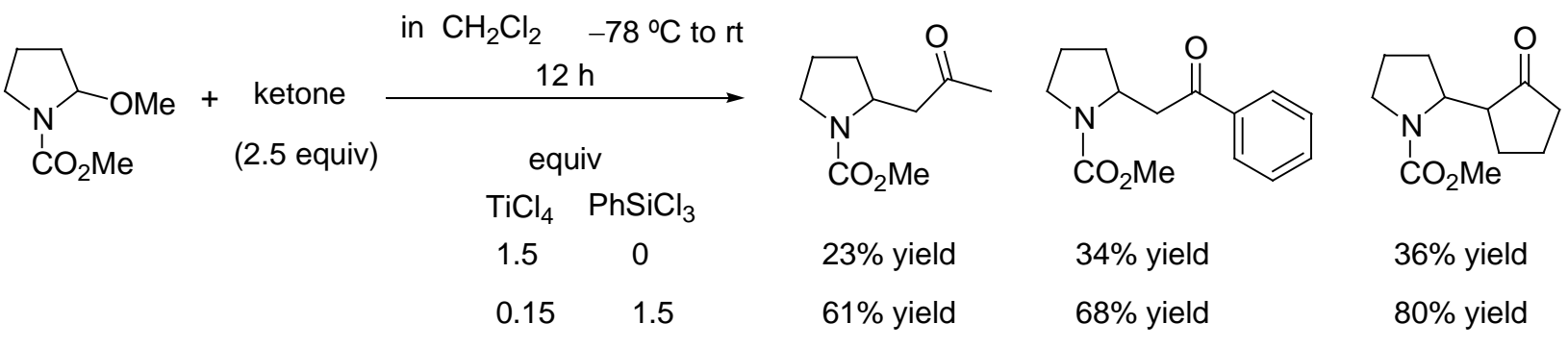

\section{3-2. Diastereoselective nucleophilic substitution}

Since nucleophilic substituition of $\alpha, \beta$-diacetate $\mathbf{G}$ majorly afforded trans- $\beta$-acetoxy- $\alpha$-substituted cyclic amines $\mathbf{H}$ in Scheme 2, it was somewhat difficult to obtain cis- $\beta$-hydroxy- $\alpha$-substituted one in high diastereoselectivity. ${ }^{11,42}$ Recently, a highly cis-selective synthesis of $\alpha, \beta$-disubstituted piperidines has been accomplished through nucleophilic additions to $N$-acyliminium ions with aryl- and alkenyl boronic acids (Eq. 8). ${ }^{43}$ 


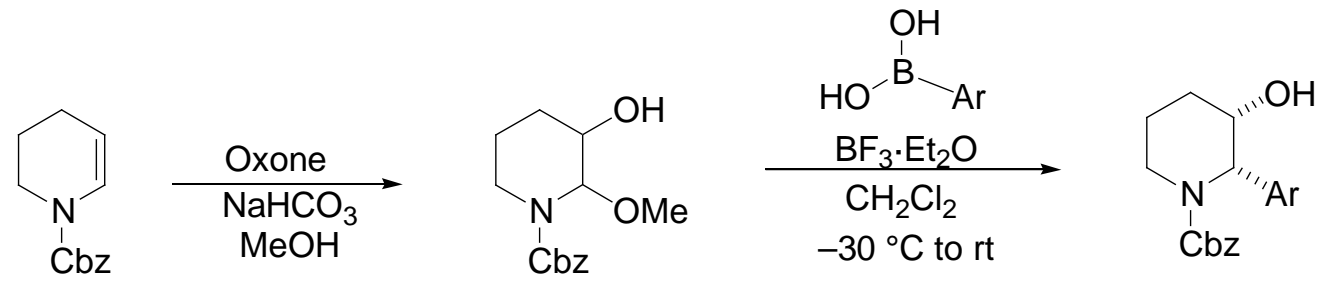

up to $90 \%$ yield

Diastereoselective nucleophilic substitution of pipecolinate derivative at the 6-position smoothly proceeded to afford cis-isomer, while control of diastereoselectivity in case of prolinate derivative was difficult. ${ }^{44}$ Recently, we found that the $N$-protecting group affected the diastereoselectivity. ${ }^{45}$ That is, $N$-methoxycarbonylated prolinnate mainly gave cis-allylated prolinate (cis/trans $=73 / 27$ ), while $N$-benzoylated prolinate preferentially changed into trans-allylated prolinate $($ cis/trans $=13 / 87)($ Eq. 9).

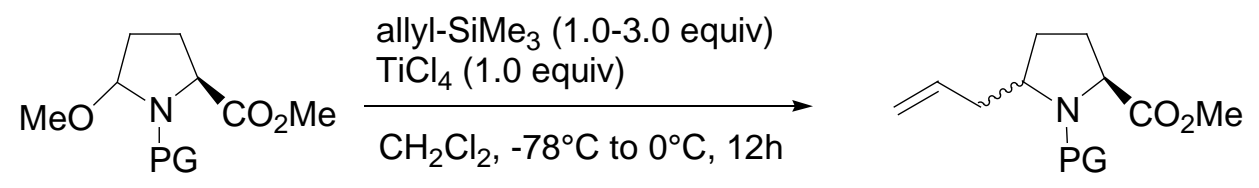

$$
\begin{aligned}
\mathrm{PG} & =\mathrm{CO}_{2} \mathrm{Me}: 80 \%(\text { cis/trans }=73 / 27) \\
& =\mathrm{Bz} \quad: 53 \%(\text { cis/trans }=13 / 87)
\end{aligned}
$$

Arylation of 5-methoxylated L-prolinates showed similar tendency to their allylation (Eq. 10).

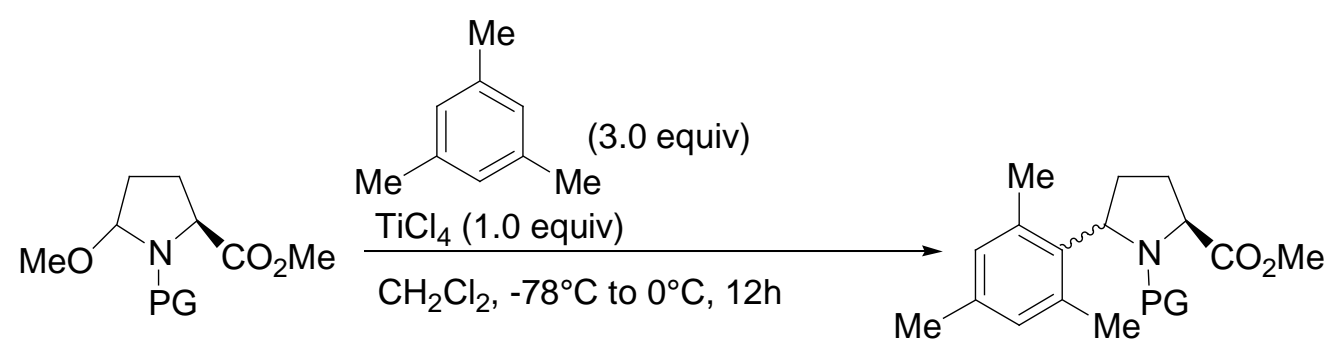

$$
\begin{array}{rlrl}
\mathrm{PG} & =\mathrm{CO}_{2} \mathrm{Me}: 51 \%(\text { cis/trans }=100 / 0) \\
& =\mathrm{Cbz} \quad: 68 \%(\text { cis/trans }=100 / 0) \\
& =\mathrm{Bz} & : 65 \%(\text { cis/trans }=11 / 89)
\end{array}
$$

This diastereoselective arylation was applicable to preparation of cis-5-arylated $N$-formyl-L-proline ${ }^{46}$ or $\mathrm{C}_{2}$-symmetrical pyrrolidine derivative ${ }^{45}$ which worked well as an organic activator in the enantioselective reduction of ketones or imines with $\mathrm{Cl}_{3} \mathrm{SiH}^{47}$ in high enantioselectivities (Eqs. 11 and 12).

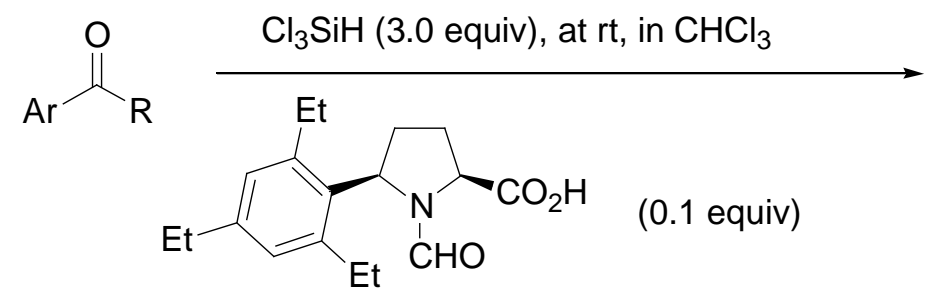

$$
\begin{gathered}
\text { up to } 99.7 \% \text { ee } \\
(99 \% \text { yield })
\end{gathered}
$$




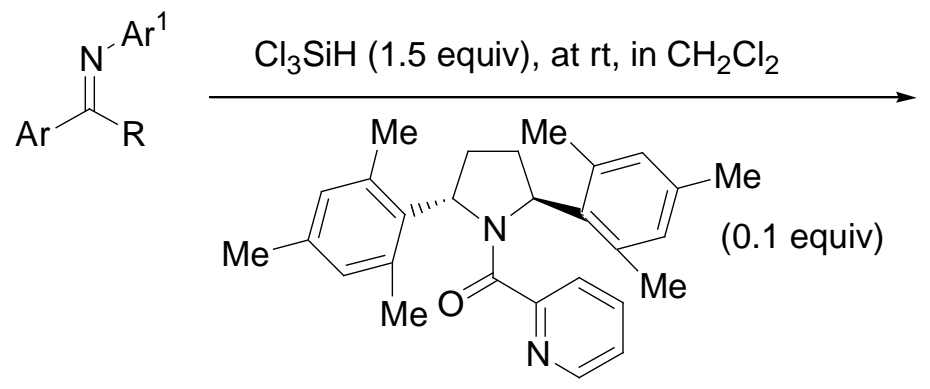

$\overbrace{\mathrm{R}} \mathrm{Ar}^{1}$

up to $85 \%$ ee

(74\% yield)

Similar effect of $N$-ptotecting group on the diastereoselectivity was observed in the Arbusov reaction of 5-methoxylated L-prolinates with phosphites in the presence of $\mathrm{BF}_{3} \cdot \mathrm{OEt}_{2}$ (Eq. 13). ${ }^{48}$

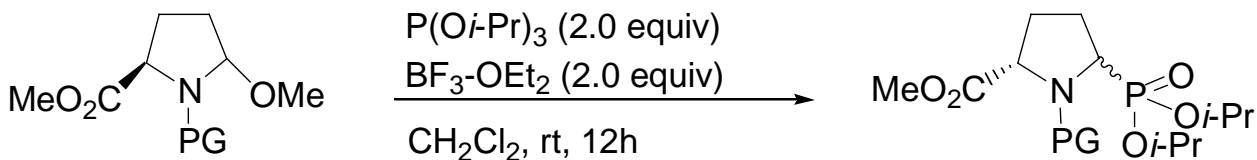

$$
\begin{aligned}
& \mathrm{PG}=\mathrm{Cbz} \quad: 50 \%(\text { cis/trans }=92.5 / 7.5) \\
& =\mathrm{Bz} \quad: 61 \%(\text { cis/trans }=8 / 92)
\end{aligned}
$$

Electrochemical oxidation of $N$-acyl- $\alpha$-allyl or benzyl amines smoothly cleaved the carbon-carbon bond to afford $\mathrm{N}, \mathrm{O}$-acetals. The allyl groups worked as chiral auxiliary to afford optically active quaternary cyclic amino acids (Scheme 18). ${ }^{49}$<smiles>C=CCC1CCCCN1CO</smiles><smiles>O=C(c1ccccc1)N1CCCCCC1</smiles>

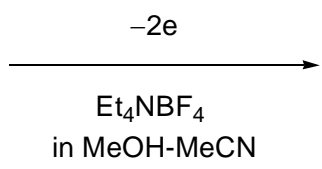

in $\mathrm{MeOH}-\mathrm{MeCN}$

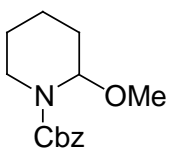

$76 \%$

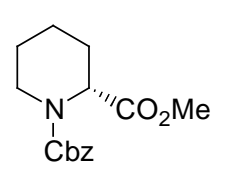

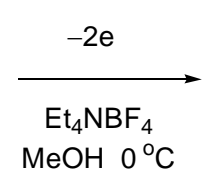

$92 \%$<smiles></smiles>

$\mathrm{Cbz}$

Allyl-TMS (1.2 equiv) $\mathrm{BF}_{3} . \mathrm{OEt}_{2}$ (1.2 equiv)

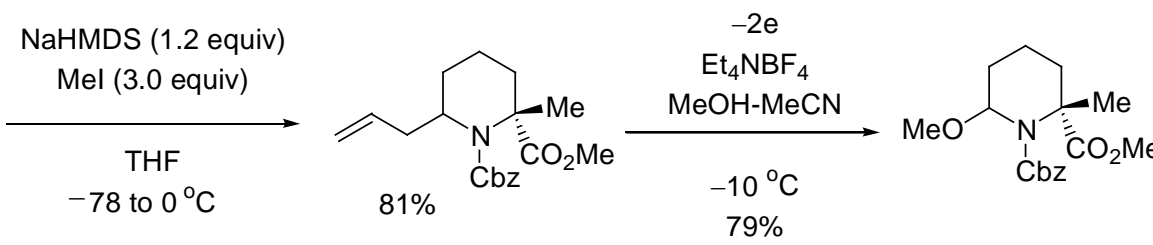<smiles>[R]OC1CCCCCCN1C(=O)O</smiles>

Scheme 18. Anodic deallylation or debenzylation

Methylphenidate has four stereoisomers since it possesses two asymmetric carbons. Among them, the threo-methylphenidate hydrochloride salt (Ritalin $\left.{ }^{\circledR}\right)$ has been used mainly for the treatment of attention deficit hyperactivity disorder (ADHD) in children in the USA. Although threo-methylphenidate was administered to patients as the racemic form, the most active enantiomer is the $d$-threo-isomer. $\mathrm{TiCl}_{4}$ 
mediated nucleophilic substitution of $\mathrm{N}, \mathrm{O}$-acetal with Evans imide proceeded to afford a precursor for $d$-thereo-methylphenidate in highly diastereoselective manner (Eq. 14). ${ }^{50}$

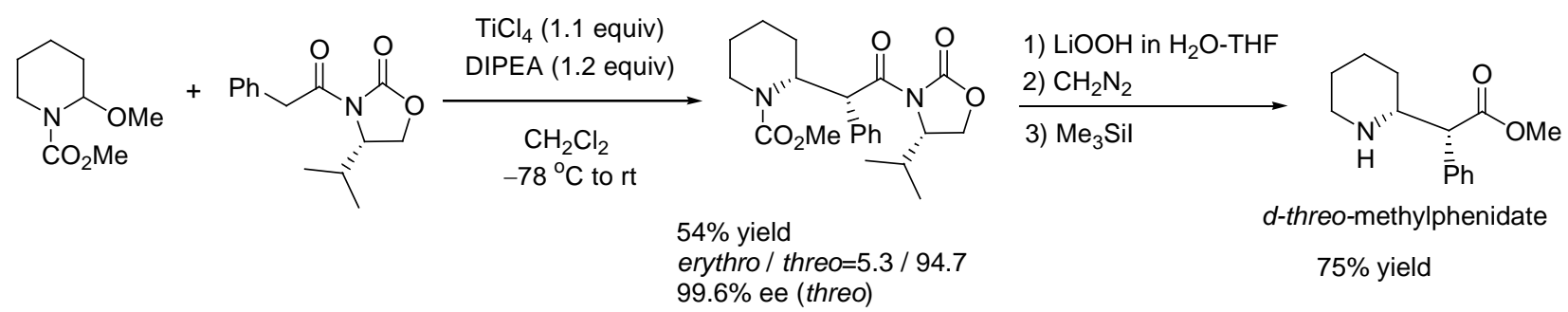

\section{3-3. Enantioselective nucleophilic substitution}

Enantioselective introduction of carbon nucleophiles $\left(\mathrm{Nu}^{-}\right)$onto cyclic $N$-acyliminium ions has attracted much interest because it provides an efficient route for elaboration of optically active piperidine and pyrrolidine derivatives. The reaction of $\alpha$-methoxypyrrolidine with silyl enol ether in the presence of a chiral titanium catalyst to afford substituted product as a mixture of diastereomers in $68 \%$ de with $53 \%$ ee for major diastereomer (Eq. 15). ${ }^{51}$
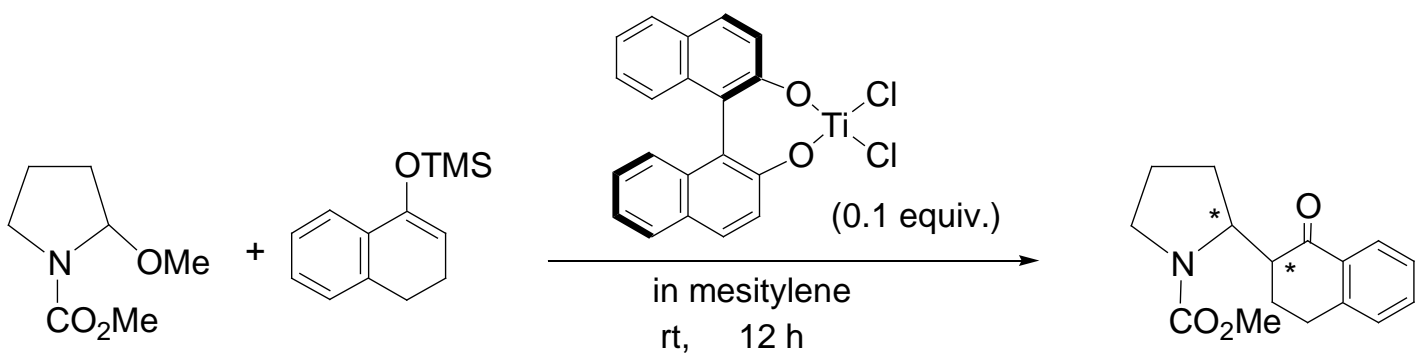

$$
\begin{aligned}
& >99 \% \text { yield } \quad 68 \% \text { de } \\
& 53 \% \text { ee (major) / } 22 \% \text { ee (minor) }
\end{aligned}
$$

A facile method for a copper ion-catalyzed asymmetric introduction of malonate group into the 2-position of 3,4-didehydro-2-methoxypiperidines with excellent enantioselectivity is shown in Eq. 16, ${ }^{52}$ while introduction of acetoacetate group proceeded in low diastereoselectivity with high enantioselectivity (Eq. $17) .^{53}$

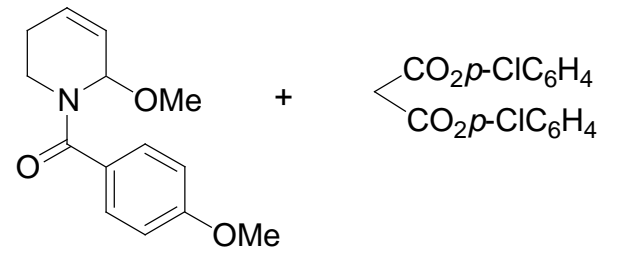

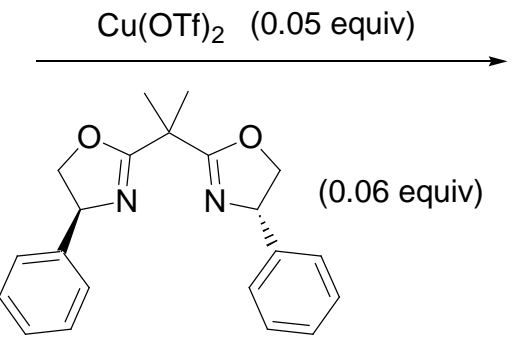

in THF, $0^{\circ} \mathrm{C}$<smiles>CCOC(=O)C(C(=O)OC(=O)OC)C(C(=O)OCC)C1C=CCCN1C(=O)c1ccc(OC)cc1</smiles>

$57 \%$ yield $97 \%$ ee 

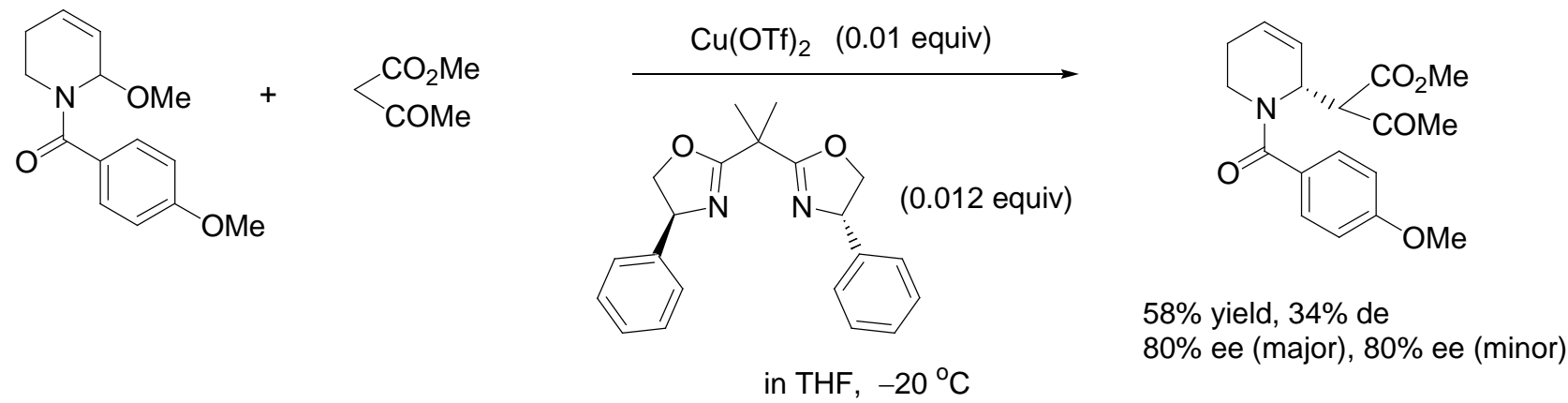

On the other hand, chiral copper ion-catalyzed coupling reaction of $\alpha$-methoxylated $\beta$-ethyl- $\beta, \gamma$-didehydropiperidines with acetoacetate proceeded to afford $\gamma$-substituted piperidines as a mixture of diastereomers in a ratio of 56/44, each of which had moderate optical purity (43-44\% ee) (Eq. 18). ${ }^{54}$<smiles>CCC1=CCCN(C(C)=O)C1OC</smiles><smiles>CC(C)(C1=N[C@@H](c2ccccc2)CO1)C1=N[C@H](c2ccccc2)CO1</smiles><smiles>CCC1=CN(C(=O)OC)CCC1C(C(C)=O)C(C)=O</smiles>

\section{3-4. Electrophilic substitution}

Regioselective introduction of various electrophiles (aldehydes, ketones, and imines) into piperidine derivatives at the 4-position was accomplished. ${ }^{55}$ Scheme 19 shows the strategy for generation of nucleophilic species from anodically prepared $N$-protected 2,3-didehydro-4-acetoxypiperidine $\mathbf{P}$, followed by generation of $\pi$-allyl palladium $\mathbf{Q}$ from $\mathbf{P}$ by $\mathrm{Pd}(\mathrm{OAc})_{2} / \mathrm{PPh}_{3}$ and then, successive umpolung of $\mathbf{Q}$ mediated by $\mathrm{Et}_{2} \mathrm{Zn}^{56}$

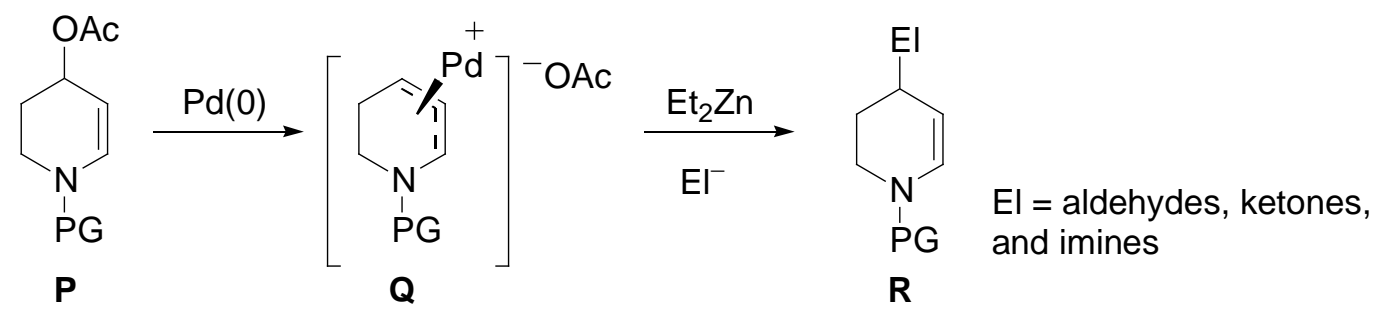

Scheme 19. Introduction of electrophile to the $\gamma$-position of piperidine skeleton

The reaction of pipecolinate derivative with acetone proceeded regio- and stereo-selectively to afford cis-2,4-disubstituted product in high yield (Eq. 19). 
Using chiral phosphine ligand afforded optically active product as a diastereomer mixture in moderate diastereoselectivity and enantioselectivities (Eq. 20).
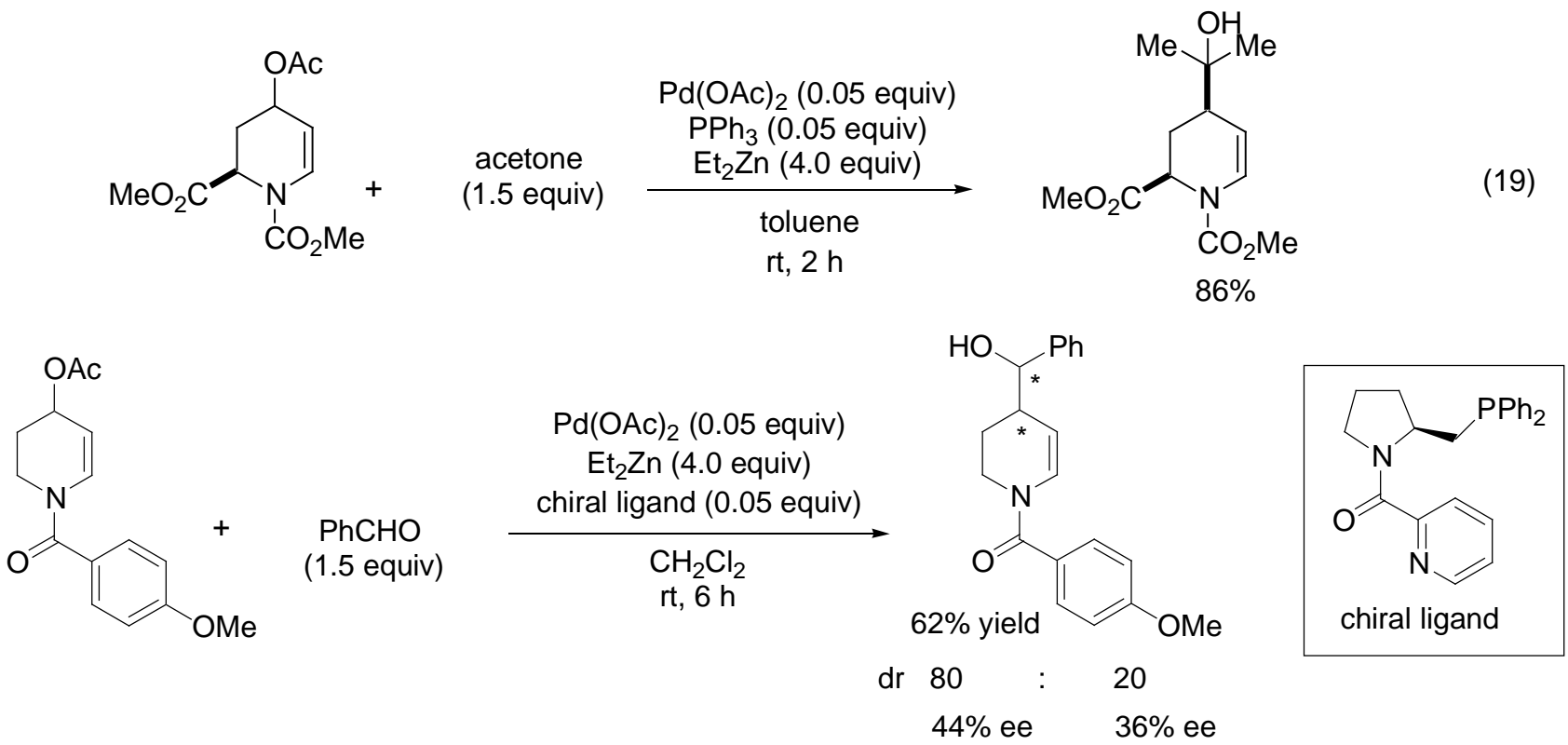

\section{3-5. Preparation of azabicyclic compounds}

Optically active 2,3-methanopipecolinic acid was prepared by procedures shown in Scheme 20 from anodically prepared cis-6-methoxypipecolinate $\left(94 \%\right.$ de). ${ }^{57}$ Firstly, cis-6-methoxypipecolinate was phenylthiolated at the 2-position by the treatment with potassium bis(trimethylsilyl)amide (KHMDS) and diphenyldisulfide, successively, and the resulting product was oxidized with $m$-CPBA to give 2,3-didehydropipecolinate. The treatment of 2,3-didehydropipecolinate with dimethylsulfoxonium methylide in DMSO gave 2,3-methano-6-methoxypipecolinate in high deiastereoselectivity. The subsequent reductive elimination of its 6-methoxy group was nicely done by adding $\mathrm{NaBH}_{4}$ to afford 2,3-methanopipecolinate in $85 \%$ ee. Finally, its hydrolysis by trimethylsilyl iodide afforded (2S,3R)methanopipecolinic acid.

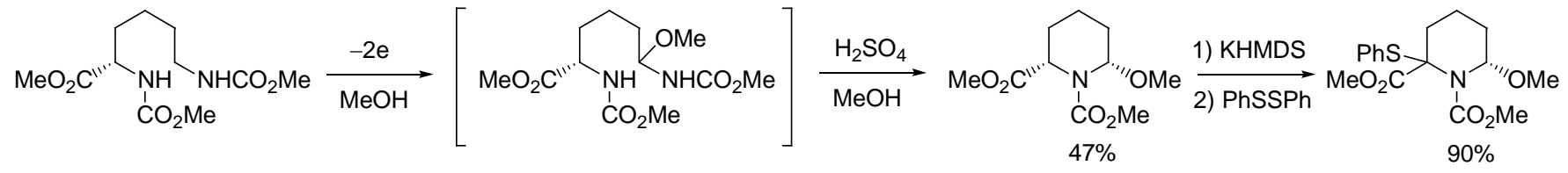
cis / trans $=94: 6$

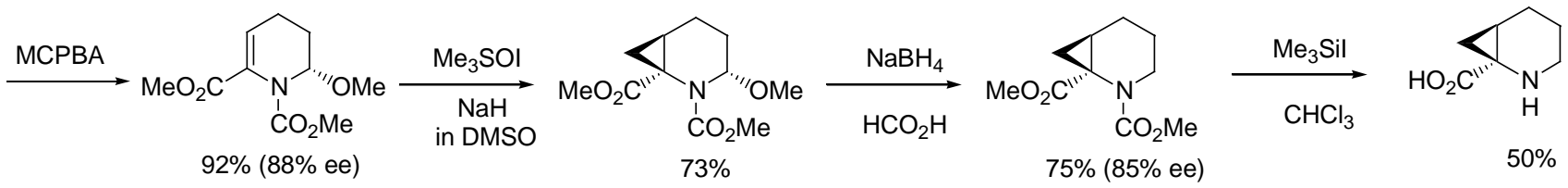

Scheme 20. Preparation of optically active 2,3-metanopipecolinic acid 
Although anodically prepared optically active 1,2-bis(methoxycarbonyl)-1,2-dihydropyridine was converted to the corresponding 1,2-dihydropyridine, the optical purity was partially lost (77\% ee) (Eq. 21). ${ }^{58}$

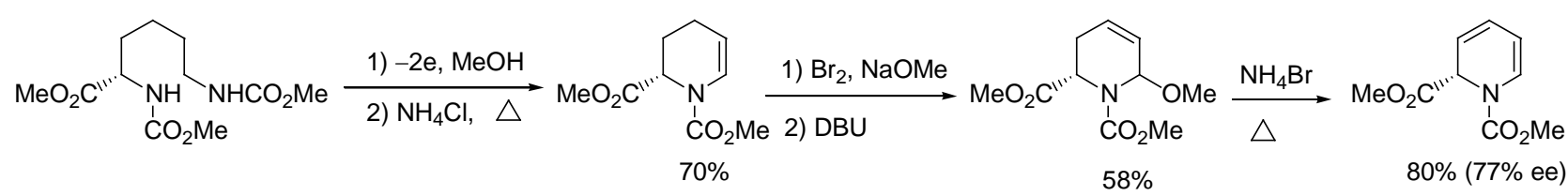

On the other hand, the corresponding acetoxymethylated compound was obtained in $>99.9 \%$ ee (Eq. 22). ${ }^{59}$

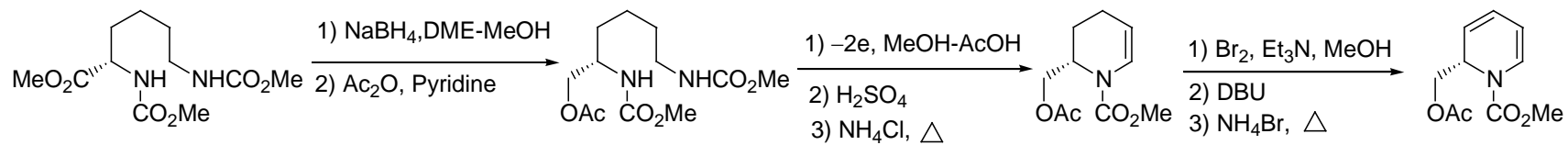

$$
\begin{aligned}
& 89 \% \quad 66 \% \quad 79 \% \quad>99.9 \% \text { ee }
\end{aligned}
$$

The enantiomerically pure dihydropyridine reacted with $N$-acryloyloxazolidinone in the presence of $\mathrm{AlCl}_{3}$ to afford anti-endo isoquinuclidine derivative in high diastereoselectivity (96.8\% de) (Eq. 23).

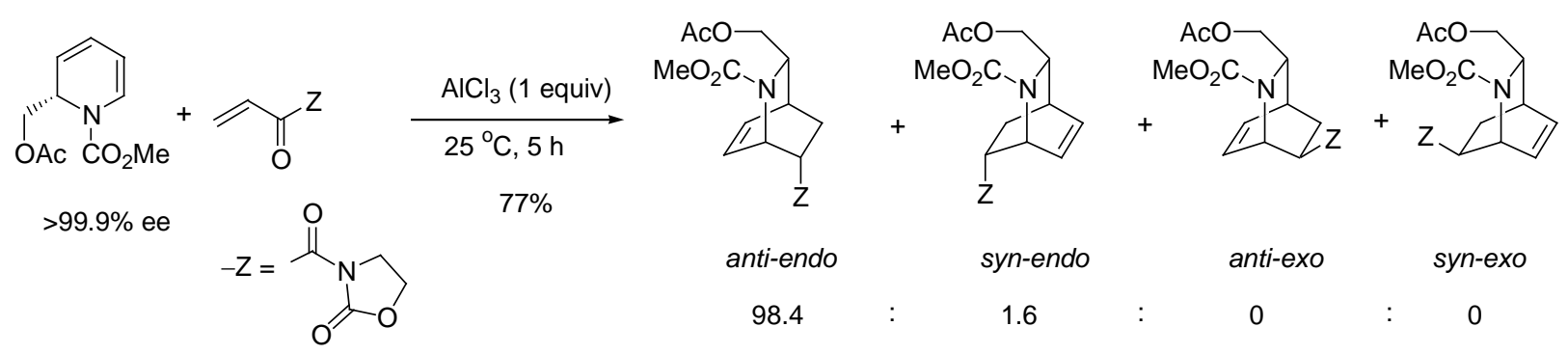

A versatile organocatalyst 2,2,6,6-tetramethylpiperidine- $N$-oxyl (TEMPO) has been utilized in chemical ${ }^{60}$ and electrochemical oxidation ${ }^{61}$ of alcohols as a mediator. TEMPO is a stable but sterically hindered radical because of the four methyl groups adjacent to the nitroxyl group. Therefore TEMPO is not suitable for the oxidation of sterically hindered alcohols. In 2006, Iwabuchi reported an excellent oxidation of sterically hindered alcohols using 1-methyl-2-azaadamantane- $N$-oxyl (1-Me-AZADO), which is one of the sterically less hindered class of nitroxyl radicals (Fig. 1). ${ }^{62}$ On the other hand, the ability of azabicyclo- $N$-oxyls for the oxidation was unknown.

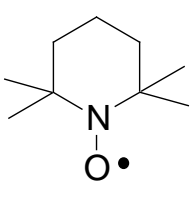

TEMPO

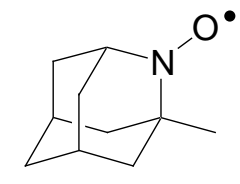

1-Me-AZADO

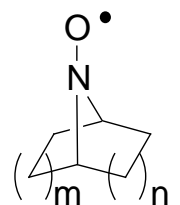

Azabicyclo- $N$-oxyls

Figure 1. Structures of some N-oxyls.

Shono and Matsumura developed preparation method for $N$-methoxycarbonyl-8-azabicyclo[3.2.1]octane 
and $N$-methoxycarbonyl-9-azabicyclo[3.3.1]nonane (Eq. 24). ${ }^{63}$ These compounds were transformed into the corresponding $N$-oxyls and/ or $N$-hydroxyls (Eq. 25$){ }^{64}$
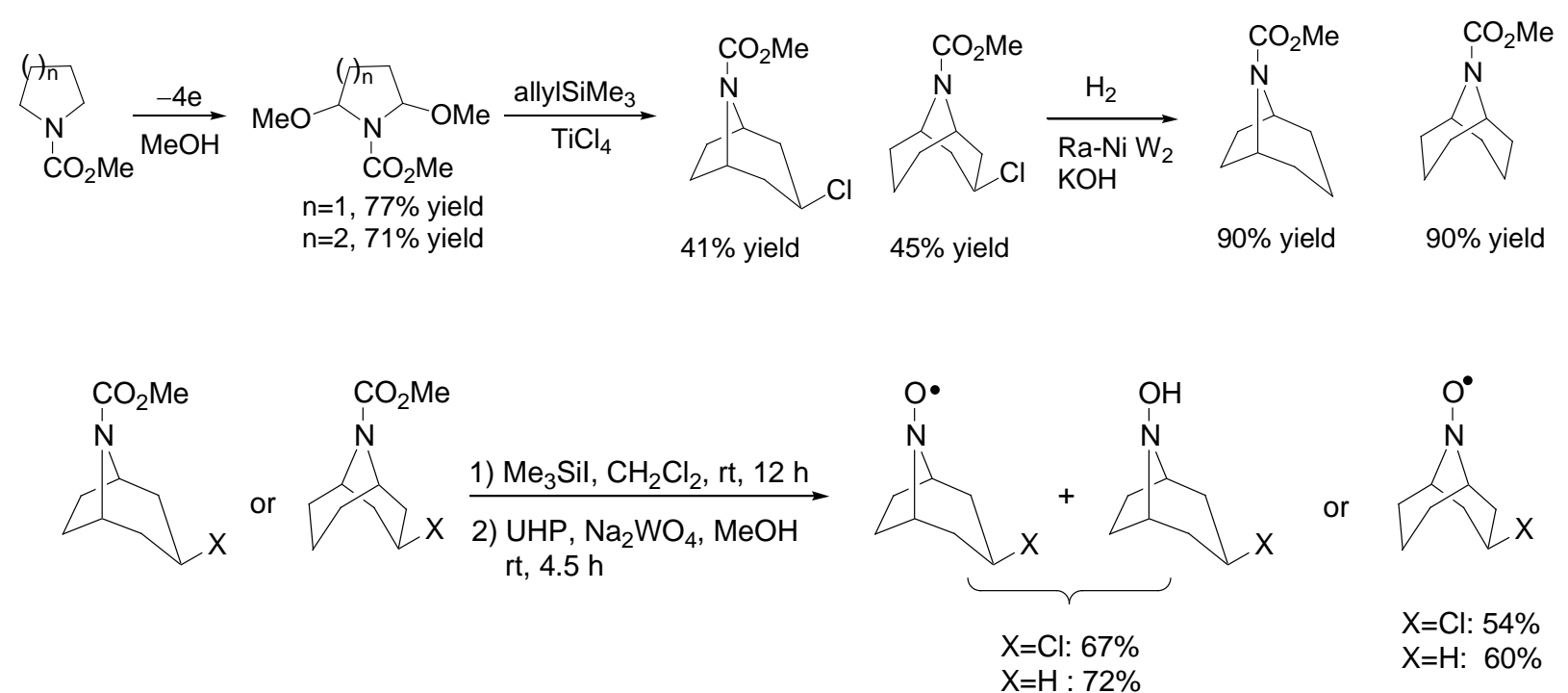

These $\mathrm{N}$-oxyls and/ or $\mathrm{N}$-hydroxyls were applicable to chemical and electrochemical oxidation of sterically hindered alcohols as mediators (Scheme 21).

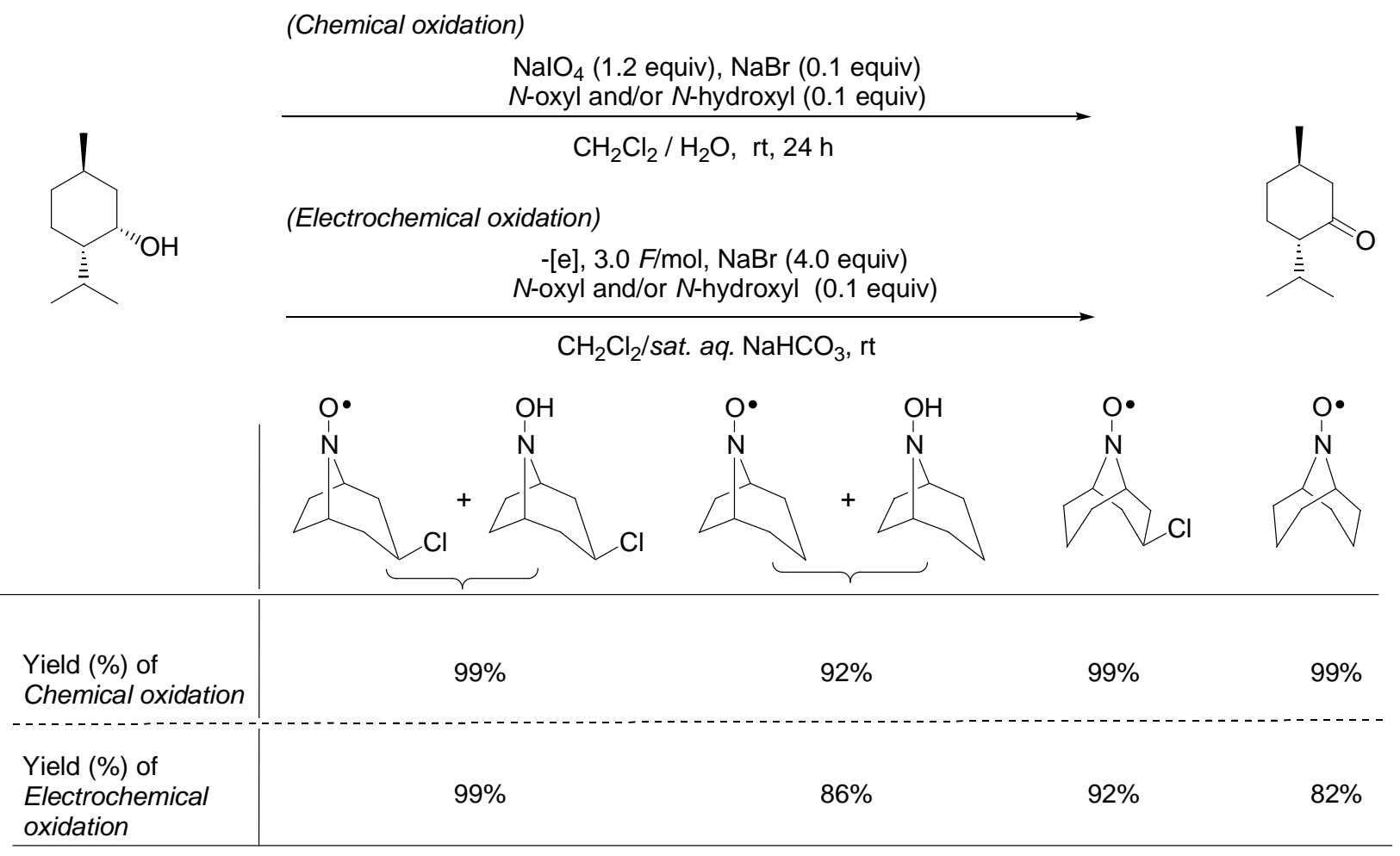

Scheme 21. $N$-Oxyl mediated oxidation of menthol

Similarly, chitral azabicyclo- $N$-oxyls were prepared by utilizing anodic oxidation starting from L-hydroxyproline $^{65}$ and D-pipecolinic acid ${ }^{66}$ as shown in Schemes 22 and 23. 
<smiles>CCOC(=O)C1CC(O)CN1C(C)=O</smiles>
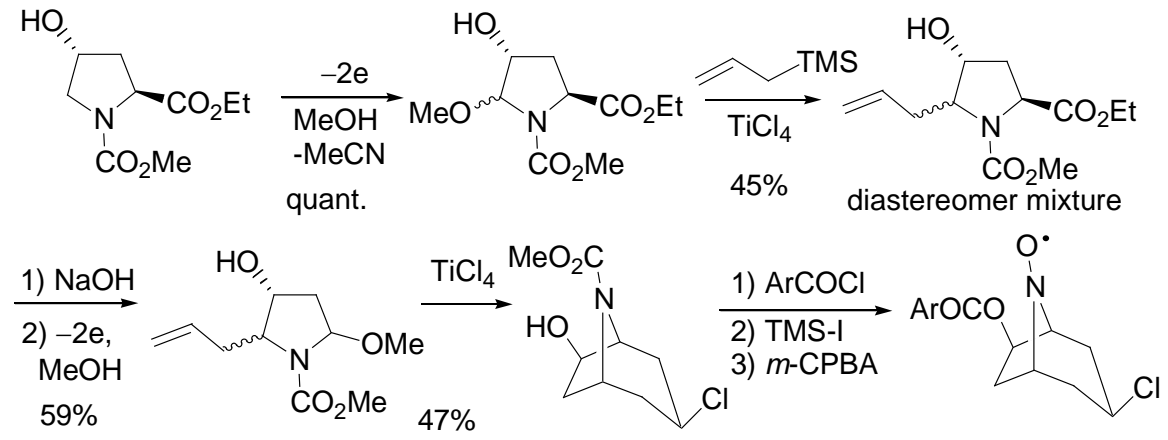

Scheme 22. Preparation of chiral $N$-oxyls from L-hydroxyproline

These chiral $\mathrm{N}$-oxyls mediated kinetic resolutions of secondary racemic alcohols in moderate $s$-values (Eq. 26).

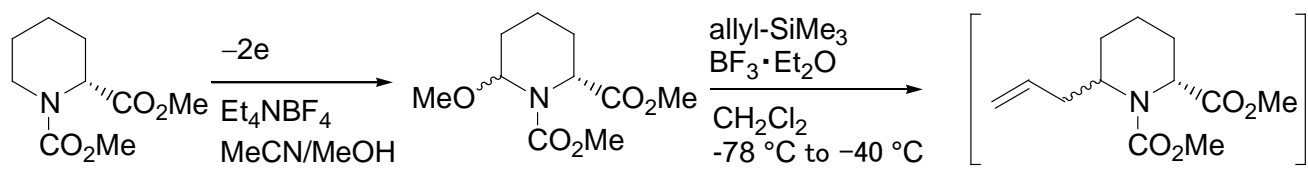
$98 \%$ cis : trans $=99.5: 0.5$

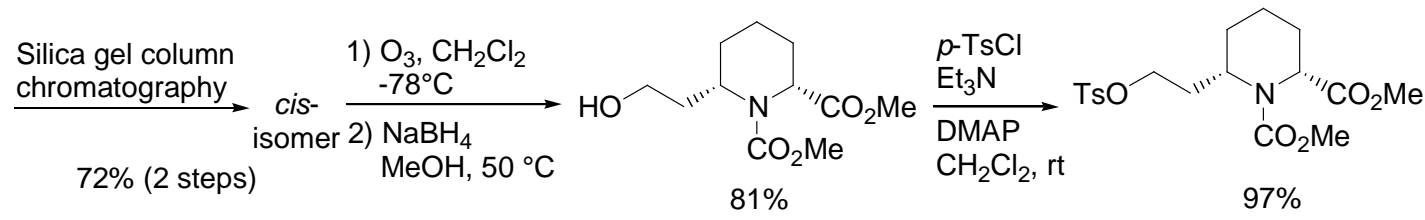

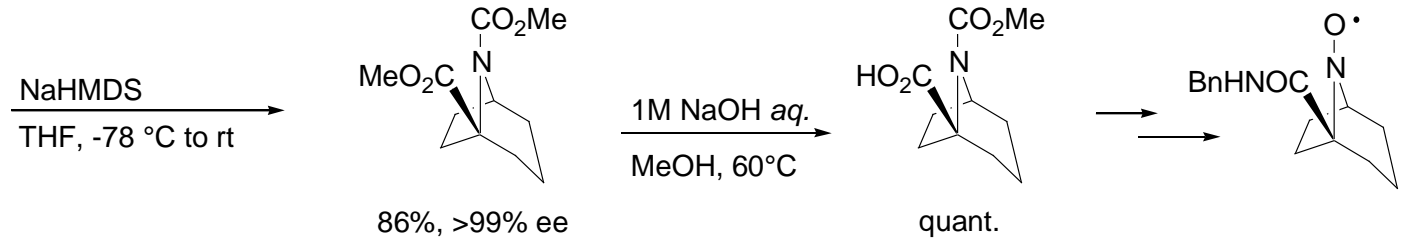

Scheme 23. Preparation of chiral $N$-oxyl from D-pipecolinic acid

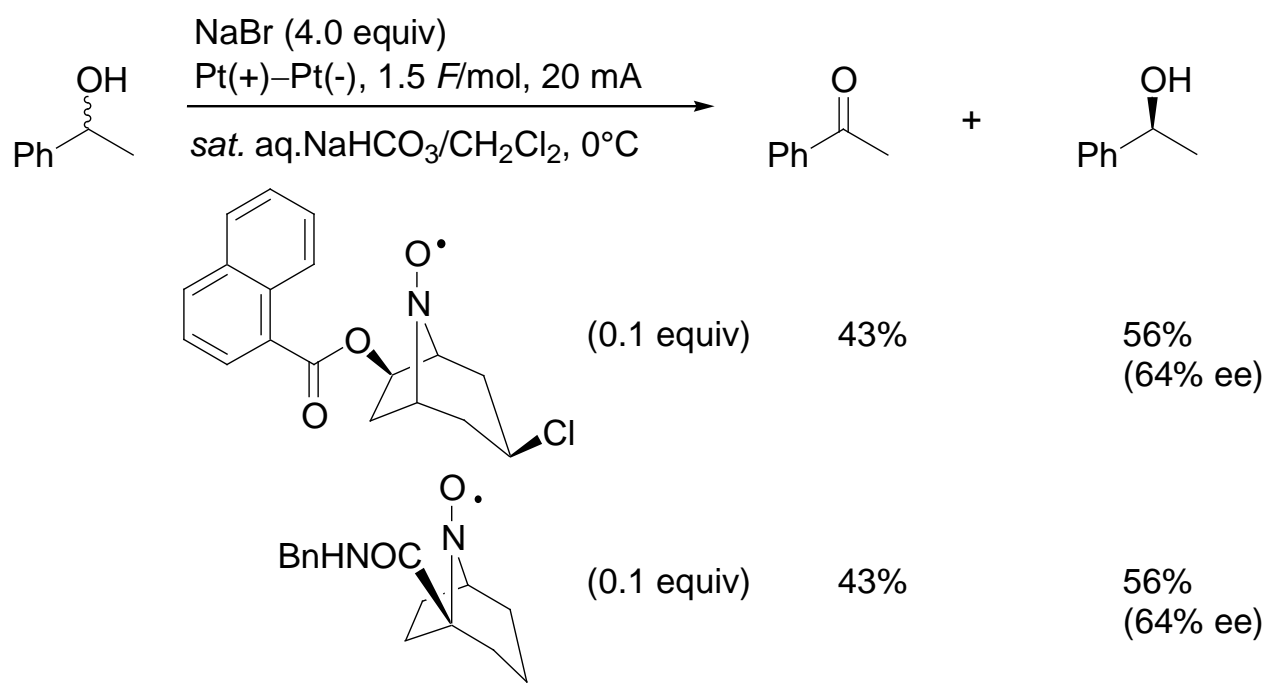


Some chiral $\mathrm{N}$-oxyls shown in Figure 2 mediated oxidative kinetic resolution of racemic amines and/or alcohols. $^{67-69}$

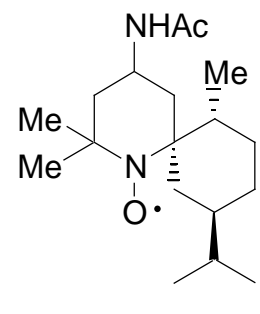

Osa $^{67}$

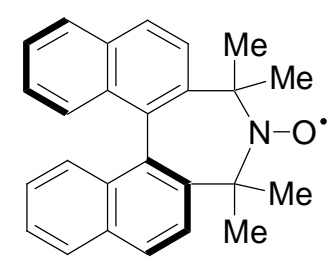

Tanaka $^{68}$

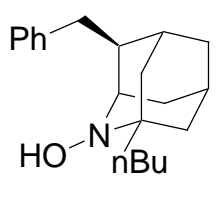

Iwabuchi $^{69}$

Figure 2. Representative chiral $N$-oxyls and $N$-hydroxyl

\section{CONCLUSION}

This review focused on some subjects on electro-organic synthesis, such as control of chemoselectivity, regioselectivity, diastereoselectivity, enantioselectivity, and their important synthetic applications. These developments for the subjects outlined above, may increase the potential of anodic synthesis. Since anodic reaction usually occurs on surface of electrode, in future, the synthesis in heterogeneous medium might afford different progress from chemical synthesis which is usually in homogeneous medium.

\section{ACKNOWLEDGEMENT}

I express my heartfelt gratitude to the late Prof. Y. Matsumura for his helpful guidance.

\section{REFERENCES AND NOTES}

1. E. Steckhan, In: Organic Electrochemistry, 4th ed. (ed. by H. Lund and O. Hammerich), Marcel Dekker, New York, 2001, pp. 545-588.

2. K. D. Moeller, In: Encyclopedia of Electrochemistry Vol. 8: Organic Electrochemistry (ed. By H. J. Schäfer), Wiley-VCH, Weinheim, 2004, pp. 277-312.

3. Y. Matsumura, Yuki Gousei Kagaku Kyokaishi, 1990, 48, 814; O. Onomura, Electrochemistry, 2010, 78, 194.

4. T. Shono, H. Hamaguchi, and Y. Matsumura, J. Am. Chem. Soc., 1975, 97, 4264; T. Shono, Y. Matsumura, and K. Tsubata, J. Am. Chem. Soc., 1981, 103, 1176; T. Shono, Y. Matsumura, and K. Tsubata, Tetrahedron Lett., 1981, 22, 3249; T. Shono, Y. Matsumura, and K. Tsubata, Org. Synth., 1984, 63, 206; T. Shono, Y. Matsumura, K. Uchida, K. Tsubata, and A. Makino, J. Org. Chem., 1984, 49, 300; T. Shono, Y. Matsumura, K. Tsubata, K. Uchida, T. Kanazawa, and K. Tasuda, J. Org. Chem., 1984, 49, 3711.

5. W. N. Speckamp and M. J. Moolenaar, Tetrahedron, 2000, 56, 3817; A. Yazici and S. G. Pyne, 
Synthesis, 2009, 339; A. Yazici and S. G. Pyne, Synthesis, 2009, 513.

6. J. Yoshida, S. Suga, S. Suzuki, N. Kinomura, A. Yamamoto, and K. Fujiwara, J. Am. Chem. Soc., 1999, 121, 9546; S. Suga, M. Okajima, K. Fujiwara, and J. Yoshida, J. Am. Chem. Soc., 2001, 123, 7941.

7. D. Horii, T. Fuchigami, and M. Atobe, J. Am. Chem. Soc., 2007, 129, 11692; J. Yoshida, K. Kataoka, R. Horcajada, and I. Nagaki, Chem. Rev. 2008, 108, 2265.

8. T. Tajima and T. Fuchigami, Chem. Eur. J., 2005, 11, 6192.

9. T. Siu, W. Li, and A. K. Yudin, Comb. Chem., 2000, 2, 545.

10. T. Shono, H. Y. Matsumura, K. Tsubata, Y. Sugihara, S.-I. Yamane, T. Kanazawa, and T. Aoki, J. Am. Chem. Soc., 1982, 104, 6697; T. Shono, Y. Matsumura, K. Tsubata, Y. Sugihara, Tetrahedron Lett., 1982, 23, 1201.

11. T. Shono, Y. Matsumura, O. Onomura, T. Kanazawa, and M. Habuka, Chem. Lett., 1984, 1101.

12. T. Shono, Y. Matsumura, O. Onomura, M. Ogaki, and T. Kanazawa, J. Org. Chem., 1987, 52, 536.

13. T. Shono, Y. Matsumura, O. Onomura, and Y. Yamada, Tetrahedron Lett., 1987, 28, 4073.

14. T. Shono, J. Terauchi, Y. Ohki, and Y. Matsumura, Tetrahedron Lett., 1990, 31, 6385.

15. T. Shono, Y. Matsumura, M. Ogaki, and O. Onomura, Chem. Lett., 1987, 1447.

16. Y. Matsumura, J. Terauchi, T. Konno, and T. Shono, Tetrahedron, 1993, 49, 8503.

17. O. Onomura, Y. Ishida, T. Maki, D. Minato, Y. Demizu, and Y. Matsumura, Electrochemistry, 2006, 74, 645.

18. H. Dhimane, C. Vanucci-Bacqué, L. Hamon, and G. Lohmmet, Eur. J. Org. Chem. 1998, 1955.

19. S. S. Libendi, Y. Demizu, Y. Matsumura, and O. Onomura, Tetrahedron, 2008, 64, 3935.

20. S. S. Libendi, Y. Demizu, and O. Onomura, Org. Biomol. Chem., 2009, 7, 351.

21. F. Louafi, J. -P. Hurvois, A. Chibani, and T. Poisnel, J. Org. Chem., 2010, 75, 5721.

22. N. Shankaraiah, R. A. Pilli, and L. S. Santos, Tetrahedron Lett., 2008, 49, 5098.

23. J. Yoshida, J. and S. Suga, Chem. Eur. J., 2002, 8, 2650.

24. T. Tajima and A. Nakajima, J. Am. Chem. Soc., 2008, 130, 10496.

25. S. S. Libendi, T. Ogino, O. Onomura, and Y. Matsumura, J. Electrochem. Soc., 2007, 154, E31-E35.

26. S. S. Libendi, Y. Demizu, Y. Matsumura, and O. Onomura, O. Heterocycles, 2009, 77, 311.

27. S. Furukubo, N. Moriyama, O. Onomura, and Y. Matsumura, Tetrahedron Lett., 2004, 45, 8177; N. Moriyama, Y. Matsumura, M. Kuriyama, and O. Onomura, Tetrahedron: Asymmetry, 2009, 20, 2677.

28. T. Iwasaki, H. Horikawa, K. Matsumoto, and M. Miyoshi, J. Org. Chem., 1979, 44, 1552.; T. Shono, Y. Matsumura, O. Onomura, and M. Sato, J. Org. Chem., 1988, 53, 4118; A. Zietlow and E. Steckhan, J. Org. Chem., 1994, 59, 5658. 
29. G. N. Wanyoike, O. Onomura, T. Maki, and Y. Matsumura, Org. Lett., 2002, 4, 1875; G. N. Wanyoike, Y. Matsumura, M. Kuriyama, and O. Onomura, Heterocycles, 2010, 80, 1177.

30. Y. Matsumura, Y. Shirakawa, Y. Satoh, M. Umino, T. Tanaka, T. Maki, and O. Onomura, Org. Lett, 2000, 2, 1689.; Y. Matsumura, T. Tanaka, G. N. Wanyoike, T. Maki, and O. Onomura, J. Electroanal. Chem., 2001, 507, 71; Y. Matsumura, G. N. Wanyoike, O. Onomura, and T. Maki, Electrochim. Acta, 2003, 48, 2957.

31. Recent representative literatures for Memory of Chirality: M. J. E. Resendiz, F. Family, K. Fuller, L. M. Campos, S. I. Khan, N. V. Lebedeva, M. D. E. Forbes, and M. A. Garcia-Garibay, J. Am. Chem. Soc., 2009, 131, 8425; M. Nechab, D. Campolo, J. Maury, P. Perfetti, N. Vanthuyne, D. Siri, and M. P. Bertrand, J. Am. Chem. Soc., 2010, 132, 14742; J.-S. Zhao, Y.-B. Ruan, R. Zhou, and Y.-B. Chem. Sci., 2011, 2, 937; F. Teraoka, K. Fuji, O. Ozturk, T. Yoshimura, and T. Kawabata, Synlett, 2011, 543; O. N. Faza, C. S. Lopez, and A. R. de Lera, J. Org. Chem., 2011, 76, 3791; H. Watanabe, T. Yoshimura, S. Kawakami, T. Sasamori, N. Tokitoh, and T. Kawabata, Chem. Commun., 2012, 48, 5346.

32. T. Shono, Y. Matsumura, K. Tsubata, and Y. Sugihara, Nippon Kagaku Kaishi, 1984, 1782.

33. G. N. Wanyoike, Y. Matsumura, and O. Onomura, Heterocycles, 2009, 79, 339.

34. D. Minato, H.Arimoto, Y. Nagasue, Y. Demizu, and O. Onomura, Tetrahedron, 2008, 64, 6675.

35. O. Onomura,; H. Arimoto, Y. Matsumura, and Y. Demizu, Tetrahedron Lett., 2007, 48, 8668; D. Minato, Y. Nagasue, Y. Demizu, and O. Onomura, Angew. Chem. Int. Ed., 2008, 47, 9458; T. Maki, S. Iikawa, G. Mogami, H. Harasawa, Y. Matsumura, and O. Onomura, Chem. Eur. J., 2009, 15, 5364.

36. T. Shono, Y. Matsumura, S. Katoh, and J. Ohshita, Chem. Lett., 1988, 1065.

37. H.-C. Xu and K. D. Moeller, J. Am. Chem. Soc., 2010, 132, 2839.

38. D. Minato, S. Mizuta, M. Kuriyama, Y. Matsumura, and O. Onomura, Tetrahedron, 2009, 65, 9742.

39. Y. Matsumura, T. Ikeda, and O. Onomura, Heterocycles, 2006, 67, 113.

40. Y. Matsumura, O. Onomura, H. Suzuki, S. Furukubo, T. Maki, and C.-J. Li, Tetrahedron Lett., 2003, 44, 5519.

41. S. Kamogawa, T. Ikeda, M. Kuriyama, Y. Matsumura, and O. Onomura, Heterocycles, 2010, 82, 325.

42. O. Okitsu, R. Suzuki, and S. Kobayashi, J. Org. Chem., 2001, 66, 809.

43. S. Mizuta and O. Onomura, RSC. Adv., 2012, 2, 2266.

44. T. Shono, Y. Matsumura, K. Tsubata, and K. Uchida, J. Org. Chem., 1986, 51, 2590.

45. O. Onomura, P. G. Kirira, T. Tanaka, S. Tsukada, Y. Matsumura, and Y. Demizu, Tetrahedron, 2008, 64, 7498. 
46. Y. Matsumura, K. Ogura, Y. Kouchi, F. Iwasaki, and O. Onomura, Org. Lett., 2006, 17, 3789

47. Chiral Lewis base catalyzed asymmetric reduction of ketones or imines with $\mathrm{HSiCl}_{3}$ reported by us, see: F. Iwasaki, O. Onomura, K. Mishima, T. Maki, and Y. Matsumura, Tetrahedron Lett., 1999, 40, 7507; F. Iwasaki, O. Onomura, K. Mishima, T. Kanematsu, T. Maki, and Y. Matsumura, Tetrahedron Lett., 2001, 42, 2525; O. Onomura, Y. Kouchi, F. Iwasaki, and Y. Matsumura, Tetrahedron Lett., 2006, 47, 3751; R. Šebesta, M. Mečiarová, E. Molnár, J. Czismadiová, P. Fodran, O. Onomura, and Š. Toma, J. Organomet. Chem., 2008, 693, 3131.

48. S. Hirata, M. Kuriyama, and O. Onomura, Tetrahedron, 2011, 67, 9411.

49. P. G. Kirira, M. Kuriyama, and O. Onomura, Chem. Eur. J., 2010, 16, 3970.

50. Y. Matsumura, Y. Kanda, K. Shirai, O. Onomura, and T. Maki, Org. Lett., 1999, 1, 175; Y. Matsumura, Y. Kanda, K. Shirai, O. Onomura, and T. Maki, Tetrahedron, 2000, 56, 7411.

51. O. Onomura, T. Ikeda, and Y. Matsumura, Heterocycles, 2005, 66, 81.

52. O. Onomura, Y. Kanda, Y. Nakamura, T. Maki, and Y. Matsumura, Tetrahedron Lett., 2002, 43, 3229; Y. Kanda, O. Onomura, T. Maki, and Y. Matsumura, Chirality, 2003, 15, 89; Y. Matsumura, D. Minato, and O. Onomura, J. Organomet. Chem., 2007, 692, 654.

53. O. Onomura, Y. Kanda, M. Imai, and Y. Matsumura, Electrochim. Acta, 2005, 50, 4926.

54. D. Minato, M. Imai, Y. Kanda,O. Onomura, and Y. Matsumura, Tetrahedron Lett., 2006, 47, 5485.

55. O. Onomura, N. Fujimura, T. Oda, Y. Matsumura, and Y. Demizu, Heterocycles, 2008, 76, 177.

56. Y. Tamaru, Eur. J. Org. Chem., 2005, 2647; M. Kimura, M. Shimizu, S. Tanaka, and Y. Tamaru, Tetrahedron, 2005, 61, 3709; M. Kimura, M. Shimizu, K. Shibata, M. Tazoe, and Y. Tamaru, Angew. Chem., Int. Ed., 2003, 42, 3392.

57. Y. Matsumura, M. Inoue, Y. Nakamura, I. L. Talib, T. Maki, and O. Onomura, Tetrahedron Lett., 2000, 41, 4619.

58. T. Shono, Y. Matsumura, O. Onomura, and Y. Yamada, Tetrahedron Lett., 1987, 28, 4073.

59. Y. Matsumura, Y. Nakamura, T. Maki, and O. Onomura, Tetrahedron Lett., 2000, 41, 7685.

60. Representative recent reviews: A. E. J de Nooy, A. C. Besemer, and H. van Bekkum, Synthesis, 1996, 1153; T. Sakai, Yuki Gosei Kagaku Kyokaishi, 2002, 60, 1215; A. R. Sheldon, and W. C. E. I. Arends, Adv. Synth. Catal., 2004, 346, 1051.

61. M. F. Semmelhack, C. S. Chou, and D. A. Cortes, J. Am. Chem. Soc., 1983, 105, 4492; T. Osa, U. Akiba, I. Segawa, and J. M. Bobbitt, Chem. Lett., 1988, 8, 1423; T. Inokuchi, S. Matsumoto, and S. Torii, J. Org. Chem., 1991, 56, 2416; T. Yoshida, M. Kuroboshi, J. Oshitani, K. Gotoh, and H. Tanaka, Synlett, 2007, 2691.

62. M. Shibuya, M. Tomizawa, I. Suzuki, and Y. Iwabuchi, J. Am. Chem. Soc., 2006, 128, 8412.

63. T. Shono, Y. Matsumura, K. Uchida, and K. Kobayashi, J. Org. Chem., 1985, 50, 3243. 
64. Y. Demizu, H. Shiigi, T. Oda, Y. Matsumura, and O. Onomura, Tetrahedron Lett., 2008, 49, 48.

65. H. Shiigi, H. Mori, T. Tanaka, Y. Demizu, and O. Onomura, Tetrahedron Lett., 2008, 49, 5247.

66. Y. Demizu, H. Shiigi, H. Mori, K. Matsumoto, and O. Onomura, Tetrahedron: Asymmetry, 2008, 19, 2659.

67. Y. Kashiwagi, F. Kurashima, S. Chiba, J. Anzai, T. Osa, and T. M. Bobbitt, Chem. Commun., 2003, 114.

68. H. Tanaka, Y. Kawakami, K. Goto, and M. Kuroboshi, Tetrahedron Lett., 2001, 42, 445.

69. M. Tomizawa, M. Shibuya, and Y. Iwabuchi, Org. Lett., 2009, 11, 1829. 